Portland State University

PDXScholar

8-12-1977

\title{
Educational, Sociocultural, and Phonological Obstacles for the Japanese Learner of English
}

David Howard Waterbury

Portland State University

Follow this and additional works at: https://pdxscholar.library.pdx.edu/open_access_etds

Part of the English Language and Literature Commons

Let us know how access to this document benefits you.

\section{Recommended Citation}

Waterbury, David Howard, "Educational, Sociocultural, and Phonological Obstacles for the Japanese Learner of English" (1977). Dissertations and Theses. Paper 2601.

https://doi.org/10.15760/etd.2597

This Thesis is brought to you for free and open access. It has been accepted for inclusion in Dissertations and Theses by an authorized administrator of PDXScholar. Please contact us if we can make this document more accessible: pdxscholar@pdx.edu. 
AN ABSTRACT OF THE THESIS OF David Howard Waterbury for the Master of Arts in English presented August 12, 1977.

Title: Educational, Sociocultural, and Phonological Obstacles for the Japanese Learner of English.

APPROVED BY MEMBERS OF THE THESIS COMMITTEE:

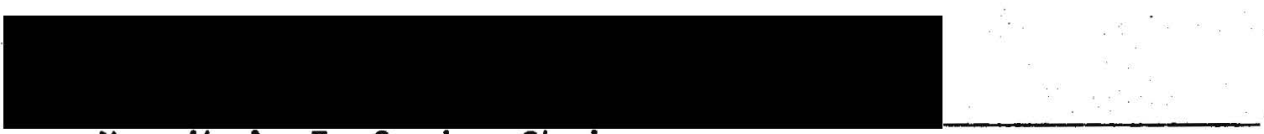

Naguib A. F. Greis, Chairman

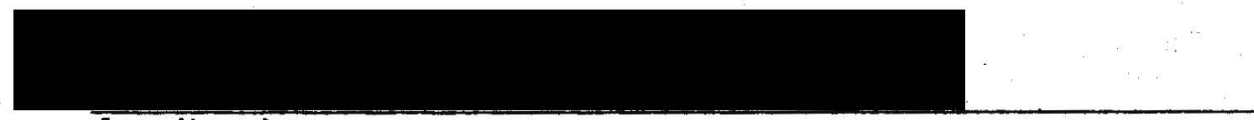

Jae Num Lee

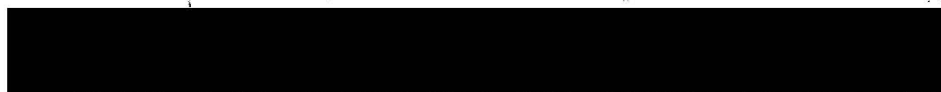

Deeanne W. Westbrook

Every Japanese high school student studies English for at least six years. However, the results of this study, especially in speaking, are poor. In the present study, educational, sociocultural, and linguistic obstacles to learning for the Japanese student are considered.

An educational system oriented toward passing college and university entrance examinations has distorted English curriculum. Furthermore, English teachers in Japan lack proficiency in the language. The teaching staffs and materials of language schools are poorly regulated. 
Concern with relative status, group identification, and loss of face acts as a deterrent to learning. For many learners the wrong type of motivation may exist.

Consideration of phonological obstacles was limited to the area of rhythm (speed, stress, word grouping, pausing). An error analys is of the speech of twenty-five Japanese students of college age was carried - out using recordings of an accent inventory. Speech was recorded both aurally and visually. No comparison of English and Japanese rhythm was made either aurally or visually. The students' speech was also rated by three native speakers for the amount of foreign accent in the area of rhythm. Three possible causes of errors were considered: language transfer, intralingual interference, and the universal hierarchy of difficulty. The source of the majority of errors was found to be due to interference. The Japanese were found to have problems in segmentation and stressing due primarily to the fact that English is a stress-timed language and Japanese is a syllable-timed one. The number of types of errors and total phonation and pause time correlated with the foreign accent rating.

The best solution to the educational obstacles facing the Japanese English learner would be the divorcement of English from the entrance examinations and a reeducation of English teachers. Native-speaking English teachers should be made aware of the cultural constraints which limit the Japanese student's learning. Future teaching programs and materials should place more emphasis on intonation and rhythm for the Japanese English learner, particularly in the grouping of words. 
EDUCATIONAL, SOCIOCULTURAL, AND PHONOLOGICAL OBSTACLES

FOR THE JAPANESE LEARNER OF ENGLISH

by

DAVID HOWARD WATERBURY

A thesis submitted in partial fulfillment of the requirements for the degree of

MASTER OF ARTS

in

ENGLISH

Portland State University

1977 
TO THE OFFICE OF GRADUATE STUDIES AND RESEARCH:

The members of the Committee approve the thesis of David Howard Waterbury presented August 12, 1977.

Naguib A. F. Greis, Chairman

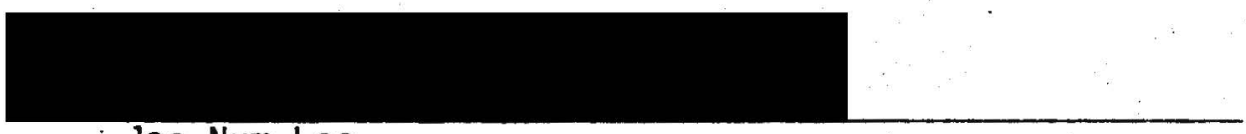

Jae Num Lee

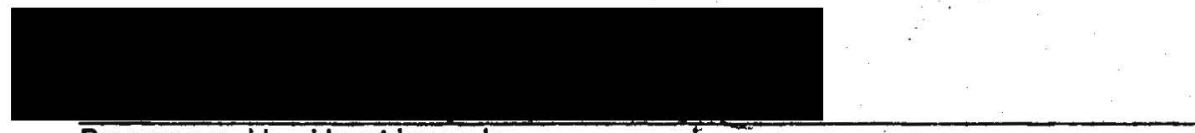

Deeanne W. Westbrook

APPROVED:

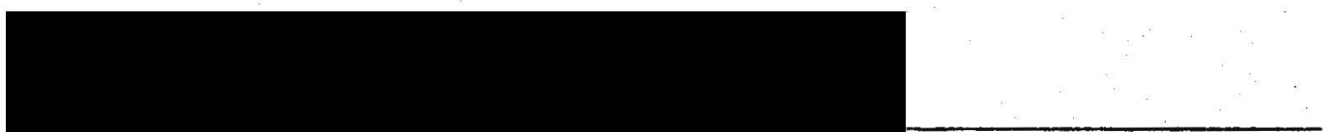

Frederick 0. Waller, Department of English

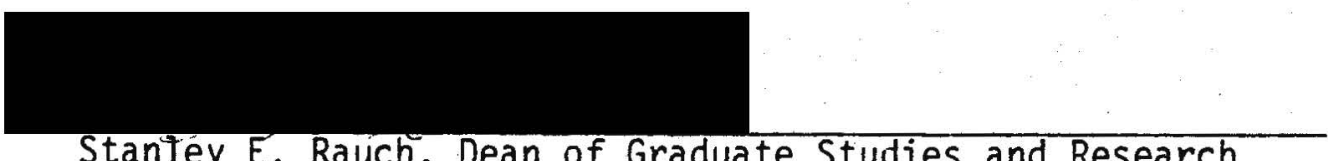

StanTey E. Rauch, Dean of Graduate Studies and Research 


\section{ACKNOWLEDGMENTS}

I wish to acknowledge my gratitude to Tadao Takekawa, associate professor of psychology at Sapporo Medical College, for his assistance and advice in the analys is of both aural and visual records of student rhythm patterns. I am also grateful to the Department of Psychology at Hokkaido University for the use of their pitch indicator. 
TABLE OF CONTENTS

PAGE

ACKNOWLEDGMENTS ...............................

LIST OF TABLES ................................. vi

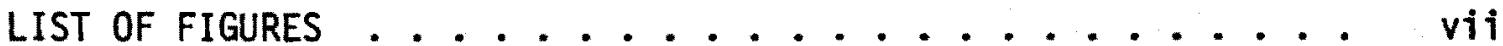

CHAPTER

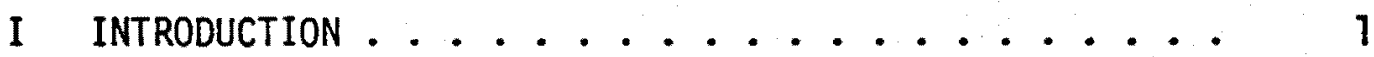

II ENGLISH EDUCATION IN JAPAN ................. 4

I. Japan's Examination System ........ 4

II. The English Teacher Dilemma ...... . 6

Present Teacher Education

Steps Toward Improvement

III. English Conversation Schools ....... 11

III CULTURAL CONSTRAINTS .............. 14

IV THE RELEVANCE OF CONTRASTIVE ANALYSIS AND

ERROR ANALYSIS TO PHONOLOGY . . . . . . . . . . 18

$\checkmark$ DESIGN OF THE INVESTIGATION ............... 24

I. Subjects ................ 25

II. Materials ........... 25

III. Methods .............. 26

VI RHYTHMIC PROBLEMS OF THE JAPANESE LEARNER $\ldots \ldots$ 
CHAPTER

PAGE

VII SOURCES OF LEARNER ERRORS . . . . . . . . . 38

I. Strong-Weak Stress Pattern ....... 38

II. Segmentation ............ 40

III. Equal Stressing ........... 41

IV. Terminal Vowel Sounds ......... 41

V. Excessive Pausing ......... 43

VI. Intralingual Interference ...... 43

VII. Grammar-Translation Study and Foreign Accent ............... 44

VIII CONCLUSIONS AND RECOMMENDATIONS .......... 46

I. Summary ................ 46

II. Conclusions .............. 46

III. Recommendations ............ 48

A SELECTED BIBLIOGRAPHY ................. 52

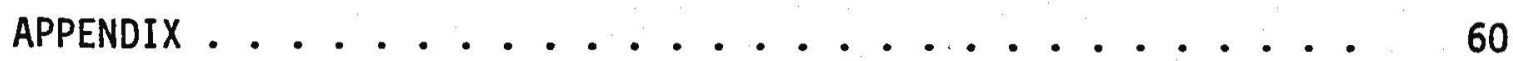




\section{LIST OF TABLES}

TABLE

PAGE

I Prator-Robinett Accent Inventory ........ 26

II Correlation of Foreign Accent Rating with Speed

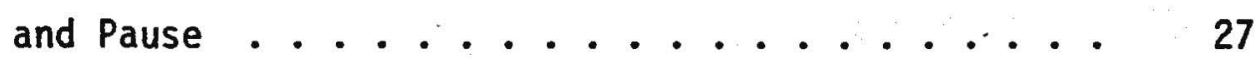

III Phonation and Pause Time of Native Speakers . . . . 27

IV Rhythmic Errors in English Speech ........ 30 


\section{LIST OF FIGURES}

FIGURE

PAGE

1 Weak Stress Observed at the End of an Interrogative

Sentence Recorded by a Japanese Speaker . . . . .

2 Strong Stress Observed at the End of an Interrogative

Sentence Recorded by a Native Speaker.......

3 Recordings of Sentence \#2 by a Native Speaker and

Subjects 13 and $18 \ldots \ldots 35$

4 Correlation between Foreign Accent Rating and Total

Phonation and Pause Time .......... 36

5 Flattening of Stress Seen in Sentence \#6 of Highest

Rated Student on Foreign Accent Rating . . . .

6 Reverse-u Correlation between Academic Records on

Translation and Subjects' Foreign Accent

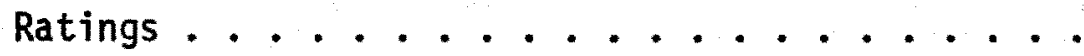




\section{CHAPTER I}

\section{INTRODUCTION}

The Japanese have every need and incentive to learn a foreign language. For the great majority, English is the only language they have the opportunity to study. They have been studying it relentlessly since the dawn of the Meiji Era (1868), when English replaced Dutch as the basic means of communication with the outside world (Gibney, 1975, p. 145). The study of English is an important part of both junior and senior high school curriculums. Although it is elective in junior high school (Ogasawara, 1976, p. 89), 91.9 percent of junior high school students have to sit for senior high school entrance examinations which include English (Torii, 1976, p. 69). The average Japanese studies English for at least the six years of junior and senior high school. If he continues his education he faces at least one additional year of Eng1ish. In addition to the English taught in public school, private English schools, institutes, courses on tape, and tutoring services can be numbered in the thousands. The English language teaching industry in Japan is a half-billion dollar a year business (Gibney, 1975, p. 146). Yet the results are not impressive. Reading and writing ability are poor and speaking ability is poorer. Some of the reasons for this involve sociocultural differences and problems within the educational system. Others involve basic linguistic differences. The objective of this thesis is to consider both of these sources of difficulty. 
In recent years one of the more important shifts in applied linguistics interest has been from the view of the teacher as the controller of language learning toward a learner-oriented view, stressing the learner's powers of hypothesis formation as he moves toward a bilingual competence sufficient for his communicative needs. One major result of this shift has been an increasing concern in monitoring and analyzing. the learner's language (Richards, 1974, p. 65). This has involved the field of error analys is--the study of the learner's errors. These errors may be indicative of both the state of the learner's knowledge and of the ways in which a second language is learned. While the learner's correct sentences do not necessarily give evidence of the rules the learner is using or the hypotheses he is testing, his errors suggest the strategies he employs to work out the rules of the new language and the rules he has developed at given stages of his language development.

The linguistic section of this thesis will be concerned with an error analysis of rhythm in the Japanese learner's English. Numerous studies have been done of English intonation (Crystal, 1969; Kingdon, 1958; Lieberman, 1967; Pike, 1945; and Sharp, 1958), some of the Japanese intonation (Abe, 1966; Bloch, 1950; and James, 1957), and at least one comparative study (Abe, 1955). Although it is unclear whether stress and pitch are separable (Bolinger, 1964; Crysta1, 1969; Denes, 1962; Lieberman, 1967; Magdics, 1963; Pike, 1945; and Schmerling, 1974), James (1957, pp. 35-36) felt that the Japanese speaker uses pitch rather than stress for word and sentence accent. James, Abe (1955, pp. 386-7), and Bloch (1950, pp. 201-2) found four pitch levels in Japanese intonation but stressed the fact that only two are used in usual speech. 
Although James felt that this did not necessarily make Japanese a monotonous language he did indicate that the variety in intonation was limited when compared with that of English. In a study of the foreign accent of Japanese English speakers by Takefuta and Black (1967, p. 168), melody was found to be of greatest importance in affecting a native listener's perception of foreign accent. Rhythm (defined as the timing of an utterance and including speed, stressing, grouping of words, and length of pausing) was of next importance. Articulation was of least importance. However, it was felt that a study of pitch errors in Japanese English would be too limited and that the components of English rhythm could be more successfully taught in the classroom than those of pitch. Therefore, an error analysis to find out what the Japanese learner's rhythm problems might be is carried out in this study.

Information in the following chapter will provide some indication of how difficult it may be to include rhythm or intonation practice in the Japanese classroom. 


\section{CHAPTER II}

\section{ENGLISH EDUCATION IN JAPAN}

The most important factor contributing to the Japanese learner's lack of fluency in either written or spoken English after at least six years of study is the educational system and the English curriculum within that system. The present situation in Japan in relation to the teaching of English was stated well by Harasawa (1974a, p. 32), when he said,

It is no exaggeration at all to say that the question we are to ask ourselves today is: to abolish English teaching al together or drastically change it into something incomparabiy more fruitful than it has been.

The major obstacles within the educational system which have led to this situation are the entrance examination system and the Japanese teachers of English.

\section{JAPAN'S EXAMINATION SYSTEM}

The great bulk of Japan's top leadership in every field consists of graduates of the most prestigious universities who qualified for these universities by high scores in their entrance examinations, which were in turn the result of academic excellence throughout their schooling. The close link between academic achievement and success in life is taken for granted by everyone in Japan. Families undergo economic privations in order to have their children receive the advantage of kindergarten training or later tutoring. Despite household crowding, 
children are given adequate space for their school homework, and mothers supervise them to see that they do it and live up to their other scholastic tasks (Reischauer, 1977, p. 171).

The importance of preparing for entrance examinations helps account for the seriousness with which education is taken in Japan and for its high levels of excellence, but it is also responsible for some of its chief flaws. The pressures on the examination taker are tremendous and the whole process is usually referred to as the "examination hell." Reischauer has suggested that the relatively high suicide rates for youth as well as the restlessness and rebellion of university students may be in part attributable to it. In addition, it distorts the content of all subjects he studies, including English (Bedford, 1974a, p. 35; Reischauer, 1977, p. 172).

Because it is at present difficult to test hearing or speaking ability on the large scale required in the entrance examinations (as many as 20,000 applicants take the examinations at the nation's most prestigious university, Tokyo University) English examinations emphasize gramar, translation, and reading in that order of importance (0ta, 1967, p. 663). Junior and senior high school curriculums are tailored to these priorities, and therefore little time is available for either speaking English or understanding it by ear. Concentration upon the type of complex grammatical problems which appear on the examinations has led one educator to describe English teaching in Japan as trivial (Kunihiro, 1977, p. 25). Professor Masanori Higa of Tsukuba University feels it is not clear what kind of linguistic competence Japanese students are expected to achieve in their English classes, when teachers 
are often concerned with the number and kinds of lexical items and syntactic patterns they should teach on a given day. He believes that because of this day-to-day planning the teachers tend to ignore the fundamental goals they should achieve (Kunihiro, 1977, p. 10).

However, even if greater emphasis could be placed upon the spoken facet of the language, the teachers themselves, in most cases, would not be able to make use of this opportunity at present because of their own lack of fluency. The causes for this are related to World War II and its aftermath and to licensing requirements for the teachers.

\section{THE ENGLISH TEACHER DILEMMA}

In the sense of a better balanced English program with more emphasis on spoken English, the situation within the Japanese educational system was better prior to World War II. During the Meiji Era, when Japan opened its doors to the West, all English teachers were native speakers. In the early twentieth century Japanese teachers educated in either England or the United States began to appear. These teachers taught in the middle school (the equivalent of the seventh to eleventh grades in the American system). Prior to 1947 the six-five-three-three system (the numbers corresponding to the respective years of elementary, middle, higher schools, and university) was followed. Only six years of schooling were compulsory so that not as many Japanese had the opportunity to study English. Urban middle and higher schools as well as universities employed native speakers on either a part-time or full-time basis. Due to this fact oral as well as written examinations were given to students entering higher school and universities. 
The militaristic government of Japan in the late thirties and the forties, unfortunately, brought a temporary end to the teaching of Eng1ish. English teachers were either sent to the front to fight or employed in work unrelated to the language. By the end of the war in 1945 the number of qualified teachers had been diminished. In 1946 the American Genera1 Headquarters required the Japanese government to adopt a six-three-three-four system of education (six years of elementary, three years of junior high school, three of senior high school, and four of university). Education became compulsory for nine years. The adoption of this system was announced in December, 1946, and was put into effect in April of the following year (Torii, 1976, p. 67; Reischauer, 1977, pp. 169-70). With the advent of this system practically all students in Japan would study English for at least three years. However, it also demanded a great increase in the number of English teachers. The prewar middle school English teachers were mostly sent to the new senior high schools and only a few remained at the junior high schools. A few primary school teachers who had been interested in English or English teaching were also employed. However, the majority of teachers at the junior high school level had had nothing to do with education. A number of them were repatriates from the front who returned to Japan to find their places of employment gone. A few of them were proficient, but most lacked both proficiency in the language and any acquaintanceship with teaching techniques. Due to these facts, as well as to the fact that middle and higher school students were not taught English during the war, oral examinations were dropped and have not been reinstated since (Torii, 1976, p. 69). 
Present Teacher Education

Torii (1976, p. 70) attributes the present poor ability in teaching the English language to the low standards set for teaching licenses. The holder of a second class English teacher's license for junior high school is required to take only sixteen English credits, three credits in English teaching methodology, and two credits in practice teaching at all four-year colleges and universities. Of the sixteen credits, only two are devoted to English conversation (spoken English) and composition, respectively. The remaining twelve credits are divided evenly between linguistics and literature. First class junior high school 1icenses and second class senior high school licenses require an additional sixteen credits balanced between linguistics and literature, but no additional credits in either English conversation or composition.

\section{Steps Toward Improvement}

Although this description of present English teacher education is rather negative, steps are being taken to improve the situation, and suggestions have been made for further improvements. Several hundred English teachers (the majority of them being college teachers) have studied in the United States under the Fulbright Program (Ota, 1967, p. 678; Torii, 1976, p. 69). Toward the end of 1955 a claim was raised by businessmen that English teaching in Japan should be more practical. In early 1956, ELEC (which originally stood for "The English Language Exploratory Committee" but after 1963 for "The English Language Education Council, Inc.") was established. Summer seminars in various places throughout the nation have been conducted, and trainees now number approximately 8,000 of the some 50,000 English teachers in Japan 
(Ogasawara, 1976, p. 93; Reischauer, 1977, p. 399; and Torii, 1976, p. 69). The aim of these seminars has been to improve teaching skills as well as English proficiency.

Another step in the proper direction was taken in Kumamoto Prefecture in southern Japan between 1970 and 1974. A program known as ITC (Intensive Training Course) was developed by a group of educators calling themselves CEEK (The Council on English Education in Kumamoto). Two-thirds of all the English teachers of public and private junior and senior high schools who were under the age of forty at the beginning of the program studied in eight-week intensive courses. The courses, taught five hours a day five days a week, were limited to twenty students. As with the ELEC seminars, teaching skills as well as English were emphasized. The majority of teachers were eager to attend but a number of them, extremely poor speakers, dropped out because of fear of embarrassment. Native speakers also visited rural and urban schools to give suggestions and to teach classes (Fukuda, 1975, p. 21). At present no other such program as extensive has been carried out elsewhere, a1though language laboratory facilities were available for teacher use and three- or four-day mini-seminars have been conducted. However, since 1974, there has been an English Fellows Program funded by the shared support of the Fulbright Commission, the Ministry of Education, and the prefectural boards of education in Japan. By the time this thes is is written, the program is due to be wholly funded by the Ministry of Education and the prefectural boards of education, with the cooperating organizations (The Council on International Educational Exchange, The Fulbright Commission, Japan, and Princeton-in-Asia) primarily 
responsible for recruitment, pre-departure and post-arrival orientation, and liaison with fellows during their year in Japan. Five fellows are sent for one year and are assigned duties related to English education in junior and senior high schools. Their duties involve "the introduction of model pronunciation, rhythm, and intonation to Japanese students and teachers through various activities such as school visits, audio tapes, and teacher training seminars." They may also judge speech contests or interview applicants for Scholarships to the United States if asked to do so by the prefectures. However, they do not teach in full-time teaching positions (Japan Ministry of Education, 1976).

Native speakers have also made suggestions for further improvement in the speaking ability of Japanese teachers. Bedford (1974a, p. 40) has suggested that teachers' associations assume responsibility for the quality of their members' fluency and also that a system of incentive pay be instituted. He also feels that periodical written and oral examinations should be required in order for teachers to keep their $1 i$ censes. Reischauer (1977, p. 399) believes that an effective nationwide retraining program is necessary and that early replacement of those unable to be retrained should be implemented. He feels that Japan could afford to send many old as well as new teachers abroad for prolonged periods of stay or could bring native speakers to Japan to work at special English language institutes. However, until the study of English is divorced from the entrance examinations, as Reischauer has also suggested, and the curriculum in junior and senior high schools is changed, there is little possibility that these suggestions will be implemented. Therefore, the many Japanese who wish to study spoken English will 
continue to turn elsewhere--to the English conversation schools and institutes.

\section{ENGLISH CONVERSATION SCHOOLS}

Perhaps as many as five hundred English conversation schools presently exist in Japan to satisfy the desire of Japanese to study English (Powe11, 1975b, p. 40). Business firms also employ native speakers to teach their officers who are being sent to overseas assignments (Hashimoto \& Lau, 1976, p. 75). Some, especially international organizations such as Berlitz, Time-Life, Encyclopedia Britannica, and Reader's Digest, offer reasonably good language instruction. However, a larger number are little more than moneymaking schemes. Schools range in size from one-room "fly-by-night" concerns with perhaps one native speaker to those with sophisticated language laboratories, faculties of as many as sixty teachers, and enrollments of approximately 1,500 students for both day and evening courses. Unlike the international concerns mentioned above, as well as a few Japanese schools, the majority of schools have neither careful recruitment programs for teachers nor careful testing programs for entering and "graduating" students.

There is usually a rapid turnover in the teaching staff of most English conversation schools. A number of factors account for this situation. For many schools the easiest teachers to employ are those who are in Japan on tourist visas. It takes approximately three months to process the commercial visa which is required for teaching in English conversation schools. If a prospective teacher shows an intention to remain at a school for at least one year, many schools will go through 
the procedures required for a conmercial visa but will employ the teacher while he is still on a tourist visa. Generally, these teachers' main purpose in Japan is not to teach but to study some facet of Japanese culture. Teachers at English conversation schools are required by the Japanese government to hold at least B.A. degrees but not necessarily in English.

Another reason for the rapid turnover in teaching staffs is teaching loads and remuneration. A full-time teacher at an average conversation school can expect to teach at least twenty-five hours a week. These hours may cover six days of the week and may range from early morning to late evening. The average salary of teachers teaching this number of hours in 1967 was $¥ 100,000$ (equivalent to $\$ 380$ at the present exchange rate of $¥ 265)$. The salary of a beginning senior high school teacher at the same time was $¥ 26,000$. The average salary for a conversation teacher now is approximately $\$ 150,000$ while that of a senior high school teacher is now approximately $¥ 100,000$. The cost of living for the foreigner is higher and thus his salary does not go as far. He also does not have the medical insurance benefits or unemployment benefits that a Japanese teacher has (Powe11, 1975b, p. 41).

The large majority of English conversation schools administer no form of placement examination or interview to the entering student. He is usually shown textbooks and a class schedule and makes his own decision as to his level of ability. If an interview is given, the number and type of questions are not always enough to make an objective decision for the students. Most schools award certificates of achievement upon completion of each level although students are generally passed on 
from one level to another whether they have mastered content or not. The desire of the management of these schools is not to displease the student, although such treatment may be detrimental to him. English conversation schools do fill a gap in English education in Japan but would fill it better if the standards for teaching staff, curriculum, and testing procedures were raised and both the staff and faculty of such schools had an understanding of the cultural constraints imposed on the Japanese. 
CHAPTER III

\section{CULTURAL CONSTRAINTS}

There are a number of aspects of Japanese culture which inhibit or block the learning of English or, perhaps, any other foreign language even under the best conditions. Bedford (1974a, p. 34) has called these aspects cultural constraints.

The most significant of these constraints and the most significant and distinctive feature of Japanese society is "groupism" (Bedford, 1974a, p. 36; Goldstein \& Tamura, 1975, pp. 1-2; Harasawa, 1974a, p. 33; and Reischauer, 1977, p. 127). All aspects of life are carried on by tightly organized groups which exert strong psychological influence to bind their members. Reischauer believes that the Japanese tend to overemphasize their group affiliations, attempting to interpret everything in terms of such things as personal factional alignments in politics, family interrelationships, academic cliques, and personal patronage and recommendations. They like to insist that what counts is not one's abilities but one's connections.

The concern with relative status and group identification tends to make them uneasy when meeting someone whose group status they do not know and whose ideas or behavior may, therefore, be unpredictably individualistic or at least not readily classifiable. The culture discourages contact with strangers whether they are foreign or Japanese. Those who do not conform are looked upon with disfavor. For example, 
Reischauer pointed out that most Japanese leaders have not really mastered a foreign language. There is a certain contempt for those who have mastered another language. Such people are suspected of being superficial in other matters.

The need to conform also leads to a greater concern about losing face. Ridicule is used from the earliest years of school. This leads to a situation in the study of English in which the learner uses only those sentences he is certain are correct. Due to the discouragement of contact with strangers and to the fear of loss of face, the Japanese learner is deprived of opportunities to practice and acquire English or any other foreign language (Bedford, 1974b, p. 20; Harasawa, 1974a, p. 33).

Harasawa (1974a, p. 33; 1974b, p. 63) also believes that the insularity of Japan has led to what he terms "linguistic absolutism," which is yet another constraint on language learning. He defines "linguistic absolutism" as a fatally ingrained sense that one's native language is beyond all comparison. He believes that because of this linguistic egocentrism English is not considered English by most Japanese until it is translated into Japanese.

Bedford (1974a, p. 39) feels that the spirit of group loyalty and vertical hierarchical control so permeates Japanese thinking that communication either between Japanese or between Japanese and non-Japanese is severely limited. Group organization tends to make the members extremely well-known to each other (Gibney, 1975, p. 147). Kunihiro (1977) has referred to this relationship, which makes words unnecessary in many situations, as a "community of emotion." 
Another constraint on learning is the fact that most conversational exchanges in Japanese are rigidly patterned and readily predictable (Bedford, 1974a, p. 39; Gibney, 1975, p. 147; Goldstein \& Tamura, 1975, pp. 1-2; and Reischauer, 1977, pp. 161-5). Communication between those in different groups is highly patterned and thus requires no invasion of unexplored territory. To learn a foreign language, however, a student must be ready and willing to confront the unfamiliar. Bedford believes that few Japanese people have or feel any need to be curious about other people. For the learning of a foreign language, he feels that there must be some amount of curiosity.

A further obstacle is the fact, widely assumed by the Japanese, that speaking and words mean little or nothing and that actions--usually rigidly prescribed behavior--are far more important.

Lastiy, there is the question of motivation. During the six years of English study in junior and senior high it is questionable how many students are motivated to learn the language because of an interest in it. This has been illustrated by a survey taken in Hyogo Prefecture and mentioned by Torii (1976, p. 72). Students in junior high school were asked how necessary and practical English was for them. Ninetythree percent felt it was necessary. The following year English was dropped from senior high school entrance examinations in that prefecture. After this, another survey of the students showed that 94 percent now felt the study of English was not of value. The motivation of adults may also be questioned. Obviously, the motivation of students in in-company programs (Hashimoto \& Lau, 1976) and of company employees sent to English conversation schools may be properly directed since they 
face the necessity of using the language, but for a number of others such classes may serve as recreation (Bedford, 1974a, p. 42). For them the classes are a social occasion, and more pleasure is gained from the study than from the final achievement.

Therefore, while the native-speaking English teacher who comes to Japan or teaches Japanese students in England or the United States can expect his students to have mastery of English grammar and a good reading vocabulary, he must also consider the previously mentioned educational problems and cultural constraints as well as linguistic differences in teaching these students. However, the results of contrastive analysis of Japanese and English and of error analys is of different facets of the learner's English will prove helpful in preparing materials and knowing when best to introduce them. 
CHAPTER IV

THE RELEVANCE OF CONTRASTIVE ANALYSIS AND ERROR ANALYSIS TO PHONOLOGY

In the last thirty years there have been at least two significant approaches in the analys is of learner difficulty in learning a second language. The first approach, contrastive analysis, attempts to predict the areas of difficulty and non-difficulty learners will encounter by comparing the linguistic system of the learner's native language with that of the target language. Proponents of this approach claim that those features of the target language which are similar to the learner's native language will be easy to acquire while those which show greater difference will be more difficult to master (Sridhar, 1975, p. 93).

The second approach, error analysis, examines empirically the actual errors in the target language produced by the second language learner and seeks to explain their cause. Proponents of this approach make no a priori predictions of learner difficulty based on contrastive analysis. Instead, the errors are analyzed, and where appropriate, are attributed to particular sources.

The error analysis approach was selected for use in this thesis because contrastive analys is by itself is inadequate (Sridhar, 1975, p. 94). While there is at least one drawback to error analys is in relation to syntactical and semantical errors, it does not exist with 
phonological errors. The drawback, avoidance of certain forms by the language learner, was pointed out by Duskova $(1969, \mathrm{p} .15)$ and dealt with in more detail by Schachter (1974). Duskova stressed that the lower frequency of errors does not necessarily signify that the item being considered is less difficult. Schachter argued that the error analysis approach is deficient because it is incapable of explaining the phenomenon of avoidance. She found that students may avoid the use of a particular structure in the target language because of its difficulty. However, she felt that this would not be the case with phonological errors since there would be no possibility of paraphrasing on the part of the speaker in the learning of pronunciation or intonation --at least not intentionally. If they were to do so, the simpler form would probably be classified as an error.

Error analysis of syntactical factors has been attempted with the Japanese learner of English (Niyekawa, 1968), and the influence of factors of intonation upon the perception of foreign accent by native listeners has been reported by Takefuta and Black (1967). However, there is no evidence that any error analysis has been completed on any facet of the intonation of the Japanese learner of English. The research which follows was 1 imited to the area of errors in rhythm. Rhythm was defined as encompassing speed, stressing, grouping of words, and pause. These standards were used by both Takefuta and Black and Cowen (1968, p. 39).

It is believed that seven factors may influence and characterize second language learner systems, according to Richards and Sampson (1974, p. 5). Selinker (1974, p. 37) described five processes which coincide 
with those of Richards and Sampson. The first of these is language transfer or interference from the mother tongue. This is considered by linguists doing contrastive analys is to be the major, but not the only, source of difficulty. It is also considered to be almost exclusively the source of phonological errors. George (Richards \& Sampson, 1974, p. 5) found that one-third of the deviant sentences from second language learners could be attributed to transfer, but until the role of other factors can be more clearly understood, it is not possible to evaluate the amount of systematic interference due to language transfer alone. Errors which may not be attributed to language transfer may fall within the area which Richards and Sampson describe as intralingual interference and which Selinker (1974, pp. 38-9) describes in the two processes of overgeneralization and transfer of training. Richards and Sampson define intralingual interference errors as those reflecting generalizations based on partial exposure to the target language. Selinker indicates that if errors are a result of clear overgeneralization of target language rules, then the teacher or researcher is dealing with the overgeneralization of target language linguistic materials. If the errors can be identified with training procedures, whether from textbook or teacher, then a transfer of training is apparent. The target language rule has not been explained adequately by either the textbook or the teacher.

A third factor is the sociolinguistic situation. Different settings for language use result in different degrees and types of language learning. Consideration of the sociolinguistic sitation includes distinctions as to whether learning opportunities are limited to those 
provided by the school course or are mainly outside of the school program, the effects of these differences, and the general motivational variables which influence language learning. The Japanese learner's study is usually limited to the school classroom and his motivation is of an "instrumental" type. Richards and Sampson (1974, p. 7) describe this type of motivation as that motivating a learner to study a language for largely utilitarian purposes, and not as a means for integration with members of another cultural linguistic group. This type of motivation is appropriate for short-term goals but inappropriate for the laborious task of learning a language. Detail concerning educational and sociocultural influences has already been presented in Chapters II and III.

The fifth factor affecting the second language learner's language is his age. Some aspects of the child's learning capacities change as he grows older and these may affect language learning. The child's memory span increases with age and he also acquires a greater number of abstract concepts and uses them to interpret his experiences. Aduits thus may be better prepared for language learning than children. However, children are better imitators of speech sounds. In the present study all subjects were of approximately the same age. It was felt that the factor of age would not be relevant to the study.

The sixth factor concerns the lack of stability of the learner's interlanguage or approximative system--the language of the learner existing between his native language and the target language. Such systems are usually unstable in given individuals, since there is invariably continuing improvement in learning the target language. Because 
the circumstances for individual language learning are never identical, the acquisition of new lexical, phonological, and syntactic items varies from one individual to another (Richards \& Sampson, 1974, p. 11). Because of time limitations, it was not possible to consider this factor's influence on rhythm errors. The learner's language may vary according to the modality of exposure to the target language and the modality of production. In productive modality phonological replacements have differed depending on whether the learner has been imitating utterances he has heard or has been producing spontaneous speech, according to Nemser (Richards \& Sampson, 1974, p. 6). The fifth and sixth factors, age and the succession of approximative systems, are not relevant to this thesis.

The seventh factor, universal hierarchy of difficulty, is concerned with the inherent difficulty of some forms, no matter what the background of the learner. What the learner finds difficult will also depend on the amount of the second language he has acquired. A learner's output may be organized in terms of what he finds easiest to say, which is not necessarily identifiable with what he knows, al though this is probably not true in the case of intonation. The term "universal hierarchy of difficulty" may also encompass two processes which Selinker (1971, p. 37) believes are involved in second language learning: strategies of second language learning and of second language comunication. Learner strategies are probably culture-bound to some extent, according to Selinker. Strategies for handling target language material evolve whenever the learner realizes, either consciously or not, that he has no linguistic competence with regard to some aspect of the target language. 
The strategy of communication of many learners dictates to them that they know enough of the target language in order to communicate and they stop learning.

Research was limited to three of these factors in relation to rhythm errors in the speech of Japanese learners of English: language transfer, intralingual interference (which Selinker defined as overgeneralization and the transfer of training), and the universal hierarchy of difficulty (including Selinker's strategies of second language learning and communication). The materials and methods involved in the project are included in the following chapter. 


\section{CHAPTER V}

\section{DESIGN OF THE INVESTIGATION}

The purpose of this study was to make an error analys is of the rhythm patterns (speed, stressing, grouping of words, and pausing) of Japanese learners of English both to discover which problems most greatly influence the naturalness of speech and what the sources of these problems may be. Students first recorded an accent inventory of a variety of sentences. These sentences were then played twice for a panel of three native listeners who are English teachers in Japan. They were asked to rate the naturalness of the subjects' speech in relation to the previously mentioned facets of rhythm. The tapes were then run through a pitch indicator which recorded pitch, intensity (stress), and duration. Each student's visually recorded tape was then played and analyzed for systemized errors while listening to the magnetic tape. Systemized errors were those which appeared frequently enough in all the subjects' speech that they were not considered simply a matter of guessing.

Phonation time, pause time, and the number of errors made (defined as differences from the similarly recorded tapes of three native speakers) were correlated with the rating of naturalness of speech in relation to rhythm. All of the students had had six years of English oriented toward grammar and translation as well as an additional year of translation of more complicated subject matter in college. Academic 
achievement in this first-year translation course was compared with the naturalness of speech rating to see if performance in translation had any relation to success in speech.

\section{SUBJECTS}

Twenty-five students enrolled in the second-year English conversation program of the Premedical Department of Sapporo Medical College, located in the northern Japanese city of Sapporo, were selected for this study. All had studied English for six years in junior and senior high school (for an average of three hours a week in the former and six hours in the latter) as well as for one year in college. These courses were oriented toward grammar and translation although students did have limited opportunities to speak and probably did watch and hear English conversation programs recorded or videotaped for classes or seen at home over educational television (Akiyama, 1976). Students also attended compulsory English conversation during their first year in college. Although speaking ability varied, they were all enrolled in an intermediate course of English conversation.

\section{MATERIALS}

An accent inventory of eleven sentences of varying lengths and types created by $\mathrm{Clifford} \mathrm{H.} \mathrm{Prator,} \mathrm{Jr.} \mathrm{and} \mathrm{Betty} \mathrm{Wallace} \mathrm{Robinett}$ (1972), and included in their Manual of American Pronunciation (Table I) was employed as suitable material for rating foreign accent in relation to rhythm. It had also been used by Cowen (1968) and Takefuta and Black (1967) in rating accent in general. 
TABLE I

PRATOR-ROBINETT ACCENT INVENTORY

(1) When a student from another country comes to study in the United States, he has to find the answers to many questions, and he has many problems to think about.

( 2) Where should he live ?

( 3 ) Would it be better if he looked for a private room off-campus or if he stayed in a dormitory?

(4) Should he spend all of his time just studying ?

(5) Shouldn't he try to take advantage of the many social and cultural activities which are offered ?

(6) At first it is not easy for him to be casual in dress, informal in manner, and confident in speech.

( 7) Little by little he learns what kind of clothing is usually worn here to be casually dressed for classes.

( 8) He also learns to choose the language and customs which are appropriate for informal situations.

(9) Finally he begins to feel sure of himself.

(10) But let me tell you, my friend, this long-awaited feeling doesn't develop suddenly--does it ?

(11) All of this takes practice.

\section{METHODS}

The subjects recorded the eleven-sentence accent inventory twice within a three-month period. The inventory was read by a native speaker prior to the first recording and the subjects were asked to read the inventory twice. The second recitation was recorded. During the period between the first and second recordings the sentences were practiced chorally and individually in class. The students were also provided with a check sheet which indicated aurally observed pronunciation and intonation errors.

The recordings were then presented to three native listeners employed as English teachers. The tapes were played twice to enable the 
listeners to compare the voices. The students were rated on the naturalness of their English on a scale of from one to seven (Appendix A). The results of the rating are illustrated in Table II. Phonation and pause time of native speakers are recorded in Table III.

TABLE II

CORRELATION OF FOREIGN ACCENT RATING WITH SPEED AND PAUSE

\begin{tabular}{cccc}
\hline Subject No. & Rating Score & Phonation Time & Pause Time \\
\hline 22 & 4.67 & $49.9^{\text {(sec) }}$ & $2.9^{\text {(sec) }}$ \\
6 & 4.34 & 53.5 & 5.1 \\
21 & 4.00 & 54.1 & 5.5 \\
1 & 4.00 & 56.4 & 5.2 \\
3 & 3.67 & 54.2 & 4.5 \\
17 & 3.67 & 58.9 & 10.9 \\
11 & 3.67 & 60.0 & 15.4 \\
25 & 3.67 & 60.7 & 9.0 \\
7 & 3.67 & 64.2 & 8.7 \\
20 & 3.67 & 64.7 & 11.3 \\
16 & 3.34 & 66.4 & 15.4 \\
18 & 3.34 & 72.6 & 16.0 \\
13 & 3.00 & 59.3 & 5.9 \\
23 & 3.00 & 64.1 & 20.1 \\
4 & 2.67 & 63.3 & 10.6 \\
9 & 2.67 & 69.3 & 11.0 \\
2 & 2.67 & 71.1 & 13.8 \\
8 & 2.34 & 72.7 & 15.6 \\
5 & 2.34 & 75.4 & 23.5 \\
19 & 2.00 & 63.3 & 14.2 \\
14 & 2.00 & 76.2 & 25.1 \\
15 & 1.34 & 61.2 & 9.0 \\
12 & 1.34 & 64.8 & 9.0 \\
24 & 1.34 & 83.4 & 21.6 \\
10 & 0.34 & 83.4 & 21.6 \\
\hline
\end{tabular}

TABLE III

PHONATION AND PAUSE TIME OF NATIVE SPEAKERS

\begin{tabular}{|c|c|c|}
\hline Speaker No. & Phonation Time & Pause Time \\
\hline 1 & $60.7^{(\mathrm{sec})}$ & $3.3^{(\mathrm{sec})}$ \\
\hline 2 & 54.2 & 4.4 \\
\hline 3 & 48.5 & 4.5 \\
\hline
\end{tabular}


It was felt that a visual recording was a necessity for accuracy. After considering the use of either a spectrograph or a pen writer (Leon, 1972) it was finally decided to run the tapes through a pitch indicator (Model PI-3A Japan Electronic Instruments Co., Ltd.) at the Department of Psychology of Hokkaido University. This instrument simultaneous1y records pitch, intensity, and duration of speaking time.

Phonation time, pause time, and the number of types of systemized errors made by each subject were then compared with ratings on the amount of foreign accent or naturalness of speech. The subjects' academic grades on translation were also obtained to observe whether this influenced their speaking ability in any way.

The types of errors found by the analysis will be explained in Chapter VI. In Chapter VII, the causes of these errors and the relationship of the subjects' previous translation-oriented language study will be considered. 
CHAPTER VI

\section{RHYTHMIC PROBLEMS OF THE JAPANESE LEARNER}

Strongly foreign accented speech is potentially a handicap and not merely an oddity; it is distorted speech, recognizable as such, and to that extent, discourse with restricted intelligibility (Takefuta \& Black, 1967, p. 167). Pike (1945, p. 20) has indicated that once a predominant type of general sequence is established, it builds up structural pressure which tends to force weak phonetic sequences of a slightly different type to reform into sequences of the predominant type. He has also stressed that some contours may be completely colorless in meaning, but, nevertheless, these mechanical contours may be very important for the learning of a language, since failure to use them immediately labels the speaker as a foreigner with a bad accent and hampers his freedom of style. This is the problem the Japanese learner of English faces in mastering rhythm patterns.

The type of errors made by the subjects of the study can be observed in Fable IV. They are arranged in the order in which the subjects were rated in Table II. One pattern differing from that of the native speakers appeared in the speech of all the subjects. Except for five subjects' recording of sentence \#2, a11 sentences began with strong stress and then gradually declined to weak stress at the conclusion of each sentence. Such stress at the beginning of an utterance, unless controlled purposely, is natural. The significant difference was that 
TABLE IV

RHYTHMIC ERRORS IN ENGLISH SPEECH

\begin{tabular}{|c|c|c|c|c|c|c|c|c|c|}
\hline $\begin{array}{c}\text { Student } \\
\text { No. } \\
\end{array}$ & $\begin{array}{c}\text { Terminal } \\
\text { Vowel Sound }\end{array}$ & $\begin{array}{c}\text { WH Question } \\
\text { Stres's } \\
\end{array}$ & $\begin{array}{c}\text { Strong-Weak } \\
\text { Stress }\end{array}$ & $\begin{array}{l}\text { Segmen- } \\
\text { tation } \\
\end{array}$ & $\begin{array}{c}\text { Stressing } \\
\text { Equal }\end{array}$ & $\begin{array}{l}\text { Excessive } \\
\text { Pause }\end{array}$ & $\begin{array}{l}\text { Adj/Noun } \\
\text { Stress } \\
\end{array}$ & $\begin{array}{l}\text { Pronoun } \\
\text { Stress }\end{array}$ & $\begin{array}{l}\text { Question } \\
\text { Pitch }\end{array}$ \\
\hline $\begin{array}{r}22 \\
6 \\
21 \\
1 \\
3\end{array}$ & $\begin{array}{l}x \\
x\end{array}$ & $\begin{array}{l}x \\
x\end{array}$ & $\begin{array}{l}x \\
x \\
x \\
x \\
x\end{array}$ & & $\begin{array}{l}x \\
x \\
x\end{array}$ & & & $\begin{array}{l}x \\
x\end{array}$ & \\
\hline $\begin{array}{r}17 \\
11 \\
25 \\
7 \\
20\end{array}$ & $\begin{array}{l}x \\
x \\
x\end{array}$ & $\begin{array}{l}x \\
x \\
x \\
x\end{array}$ & $\begin{array}{l}x \\
x \\
x \\
x \\
x\end{array}$ & & $\begin{array}{l}x \\
x \\
x\end{array}$ & & & & \\
\hline $\begin{array}{r}16 \\
18 \\
13 \\
23 \\
4\end{array}$ & $\begin{array}{l}x \\
x \\
x\end{array}$ & $\begin{array}{l}x \\
x \\
x\end{array}$ & $\begin{array}{l}x \\
x \\
x \\
x \\
x\end{array}$ & $\begin{array}{l}x \\
x \\
x \\
x\end{array}$ & $\begin{array}{l}x \\
x \\
x\end{array}$ & $\begin{array}{l}x \\
x \\
x \\
x \\
x\end{array}$ & $\begin{array}{l}x \\
x\end{array}$ & $x$ & $x$ \\
\hline $\begin{array}{r}9 \\
2 \\
8 \\
5 \\
19\end{array}$ & $\begin{array}{l}x \\
x \\
x\end{array}$ & $\begin{array}{l}x \\
x \\
x \\
x \\
x\end{array}$ & $\begin{array}{l}x \\
x \\
x \\
x \\
x\end{array}$ & $\begin{array}{l}x \\
x \\
x \\
x \\
x\end{array}$ & $x$ & $\begin{array}{l}x \\
x \\
x \\
x \\
x\end{array}$ & & $x$ & $\begin{array}{l}x \\
x\end{array}$ \\
\hline $\begin{array}{l}14 \\
15 \\
12 \\
24 \\
10\end{array}$ & $\begin{array}{l}x \\
x \\
x \\
x\end{array}$ & $\begin{array}{l}x \\
x \\
x \\
x \\
x\end{array}$ & $\begin{array}{l}x \\
x \\
x \\
x \\
x\end{array}$ & $\begin{array}{l}x \\
x \\
x \\
x \\
x\end{array}$ & & $\begin{array}{l}x \\
x\end{array}$ & $\begin{array}{l}x \\
x\end{array}$ & $\begin{array}{l}x \\
x\end{array}$ & \\
\hline
\end{tabular}


in general the subjects did not surpass this strong stress elsewhere in their sentences. In addition, they did not vary their stress pattern at the end of sentences whether the sentence was interrogative or indicative. The difference can be observed in Figures 1 and 2, visual recordings of sentence \#5 ("Shouldn't he try to take advantage of the many social and cultural activities which are offered?") by a Japanese speaker and a native speaker, respectively. Both the native speaker and the Japanese speaker begin with strong stress (in fact, that of the native speaker is stronger). However, the Japanese speaker's stress in other parts of the utterance does not surpass that at the beginning. The native speaker does surpass initial stress at least at one point in the sentence (on the word "cultural"). It can also be seen that the stress used by the Japanese learner at the conclusion of the sentence is greatly different from that of the native speaker. Height and width of the last word spoken by the native speaker indicate a great deal more stress and longer duration of time.

Figure 1 is also illustrative of the two problems which may be of more significance to learning English than the stress pattern described. It would be extremely difficult to change the strong-weak stress pattern, al though learners can be taught the difference of patterns for various types of sentences. Problems of segmentation and terminal vowel sounds may be more easily remedied through explanation and practice.

The number of major peaks as well as minor divisions at the tops of these peaks in Figure 1 are illustrative of the segmentation of sentences by the average and poorer speaker of English in Japan. The 


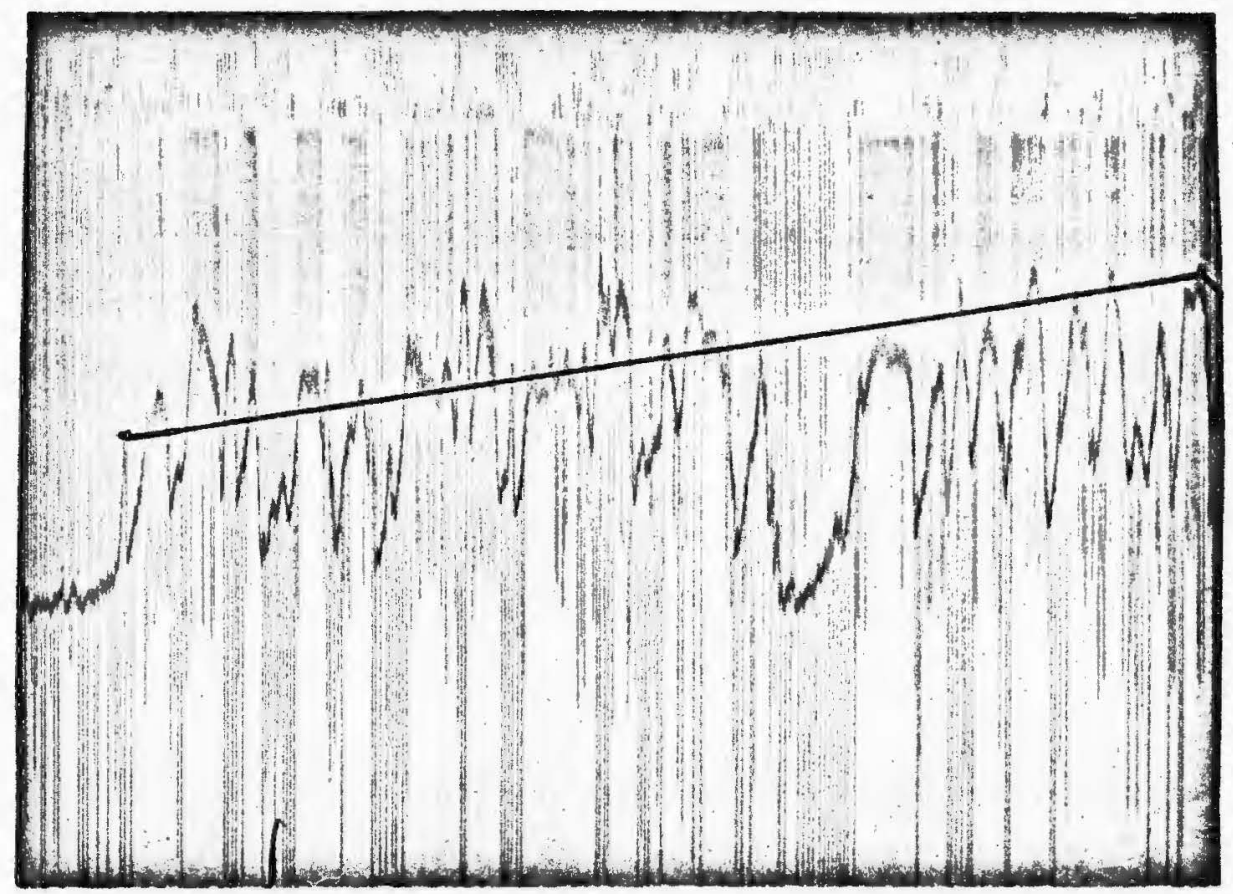

Figure 1. Weak stress may be observed at the end of an interrogative sentence recorded by a Japanese speaker. Recording should be read from right to left.

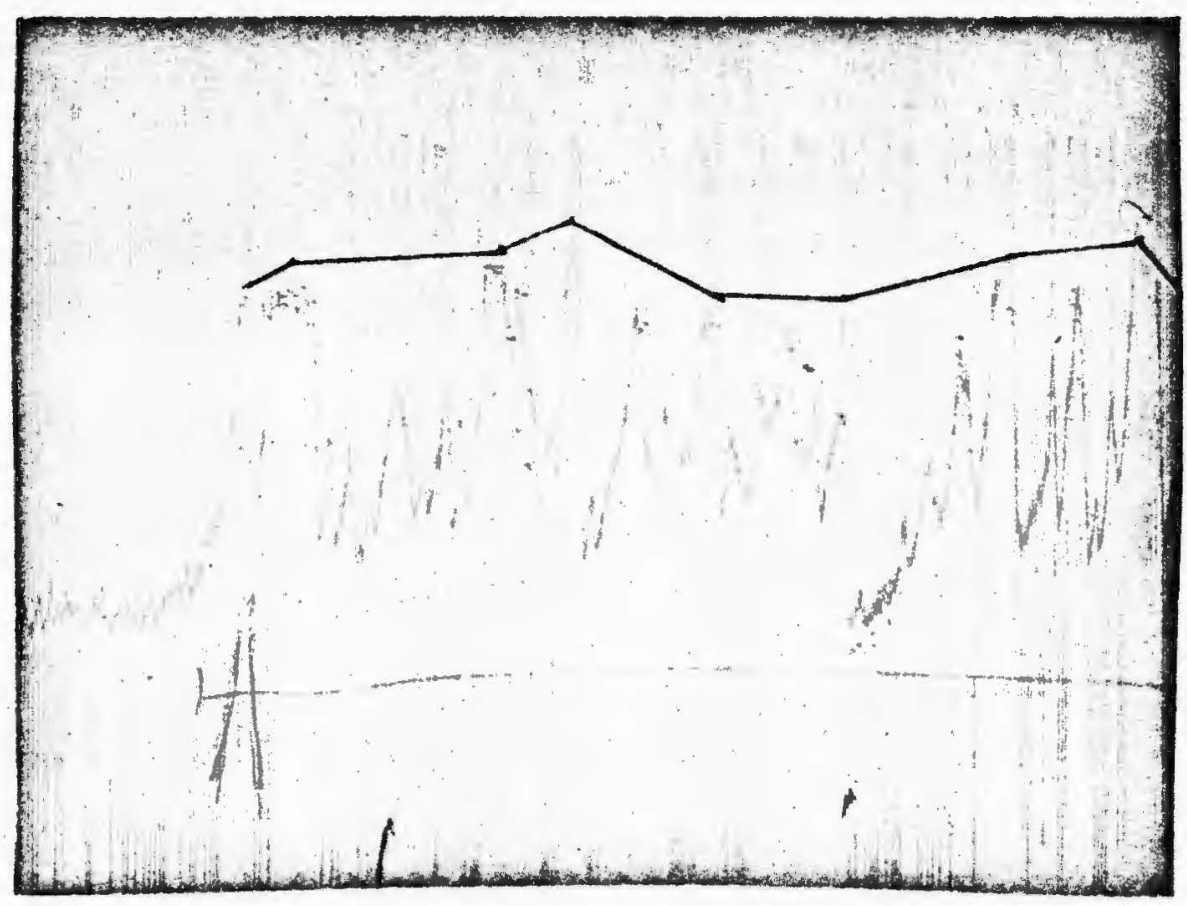

Figure 2. Strong stress may be observed at the end of an interrogative sentence recorded by a native speaker. 
speaker tends to say each word separately--he does not run them together. This not only affects his rhythm pattern, but also distorts his pronunciation. Pike (1945, p. 107) stressed the fact that experience in the English Language Institute at the University of Michigan indicated that no pronunciation of English sounds natural unless the intonation is fairly acceptable. Even with satisfactory consonants and vowels, phrases with incorrect intonation sound foreign.

The top ten speakers on the foreign accent scale were able to group their words together successfully and to speak smoothly. However, 56 percent had a problem with linking of words. While this is a problem faced to some extent by all beginning students of a foreign language, further explanation for its significance for Japanese learners will be provided in Chapter VII.

The problem of terminal vowel sounds at the end of words terminating in consonant sounds is also illustrated in Figures 1 and 2. While deep, defined "valleys" can be seen between peaks in the native speaker's recording in Figure 2, there is a lack of depth as well as clear definition in the "valleys" in Figure 1. These valleys are periods of pause. The clear-cut pattern in the native speaker's speech is illustrative of zero phonation (no speech) while the blurred pattern in the speech of the Japanese learner indicates sound is still being produced at points where there should be no sound. This softening or dulling of pauses between rhythm units or, in the case of the poor Japanese speaker, between individual words, was a problem for 60 percent of the subjects. 
A pattern of incorrect stress on the question-word question ("Where should he live?") appearing in the accent inventory was recorded in 76 percent of the subjects. Both native speakers and the subjects placed heavy stress on the initial question word but the Japanese placed measurably less stress on other words in the sentence. In the case of the five students who did approach the stress pattern of the native speakers there were deviations in other parts of the sentence. The native speakers placed equal stress on "where" and on the verb at the end of the sentence and then less stress on "should" and "he," respectively. Figure $3(a)(b)(c)$ illustrates the differences. The Japanese subject in Figure $3(b)$ placed almost identical stress to that of the native speaker on "where" and "live" but also placed approximately the same amount of stress on "should" and a great deal more on "he" than did the native speaker. The speaker in Figure $3(c)$ placed weak and almost equal amounts of stress on "should," "he," and "live."

Another problem for the subjects was excessive pausing. Figure 4 and the data in Table II illustrate a positive although not complete correlation between the foreign accent rating given the subjects and the amount of pausing they did. Fifty-two percent of the subjects paused significantly enough to influence their rating.

Segmentation was a major problem for the poorer or average student. The above-average student, in increasing his speed of speaking, tends to neglect stressing and places almost equal stress on all words. A7though a few higher peaks can be seen in Figure 5 , most of the words receive the same amount of stress and the duration of time, indicated by the width of the peaks, is almost equal. 


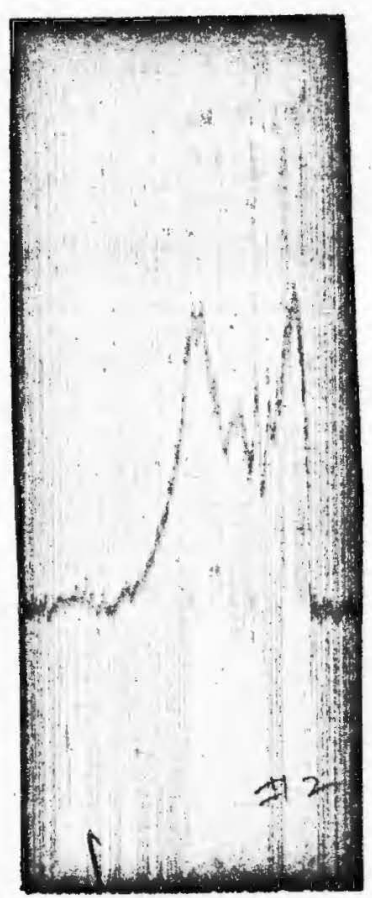

(a)

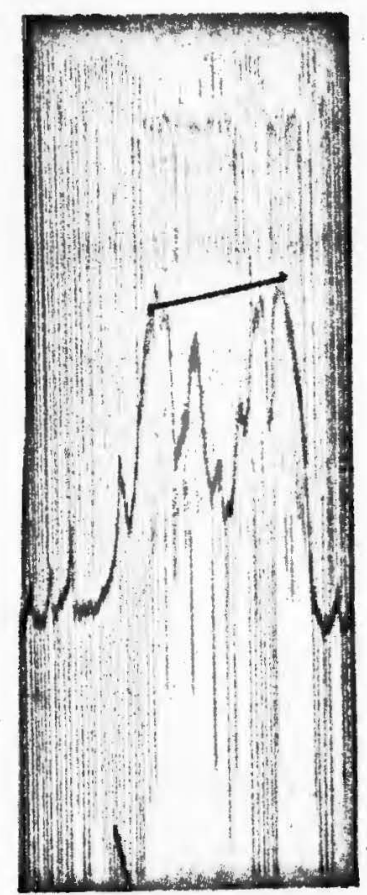

(b)

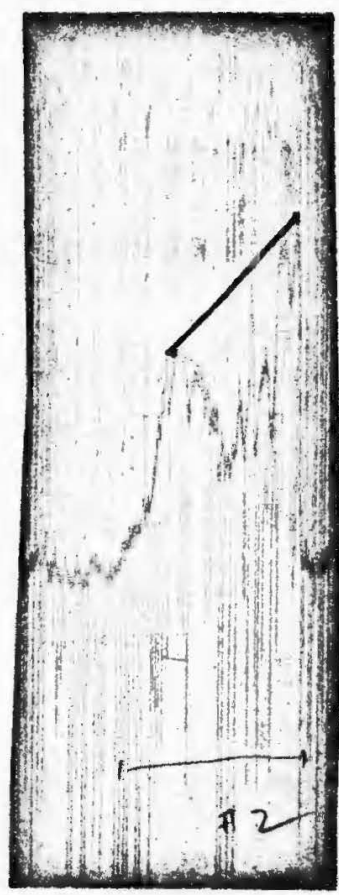

(c)

Figure 3. From left to right may be seen recordings of sentence \#2 by a native speaker and subjects 13 and 18 , respectively. The pattern of subject 18 differs greatly from that of the native speaker.

Solid circles in Figure 4 indicate the results of speakers with rating scores of 4.0 or above, solid triangles, rectangles, and $x$ 's indicate the results of learners who achieved ratings of 3.0 to $4.0,2.0$ to 3.0 , and below 2.0 , respectively. Open circle signify the native speakers' results. The best speakers can be seen to closely approach native speakers in both phonation and pause time. The contribution of pause time to total phonation time and to a poor foreign accent rating is clearly illustrated in Figure 4. 


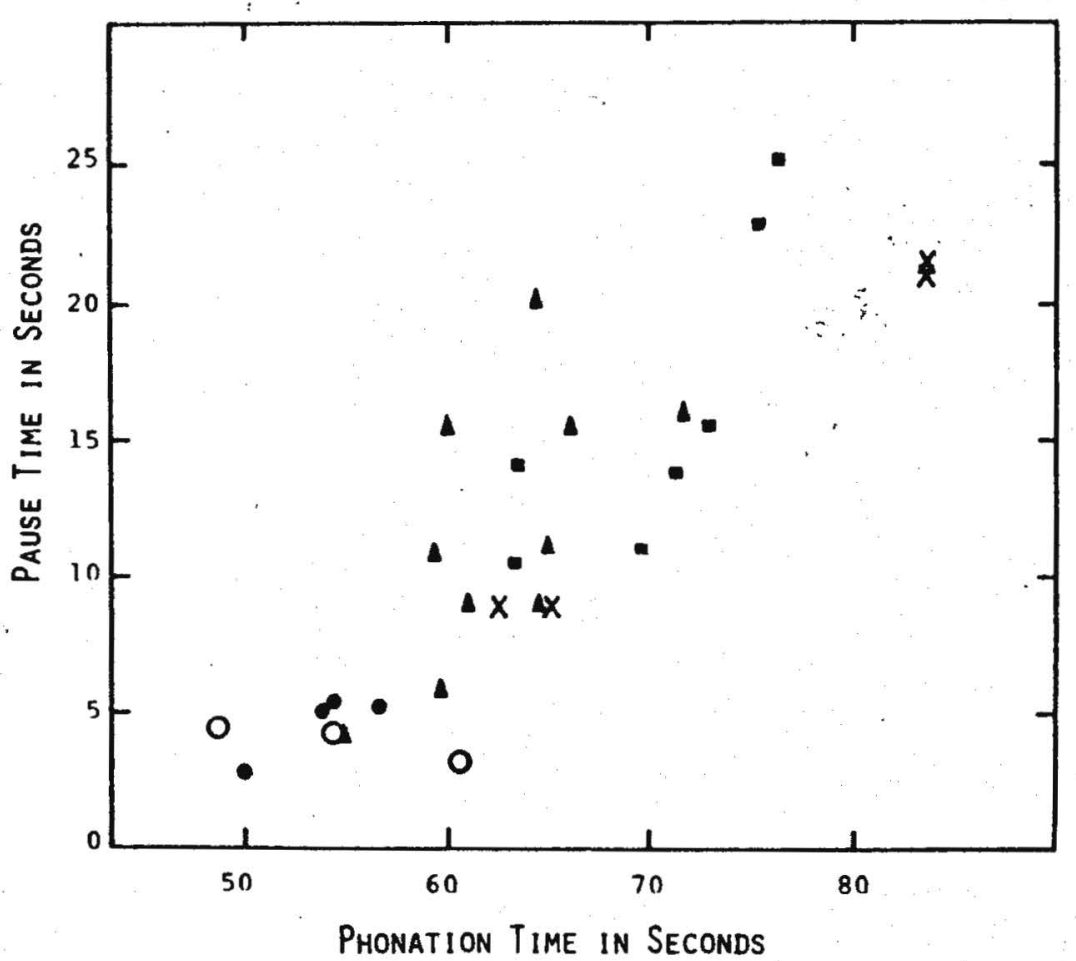

Figure 4. A graph of the correlation between foreign accent rating and total phonation and pause time. 


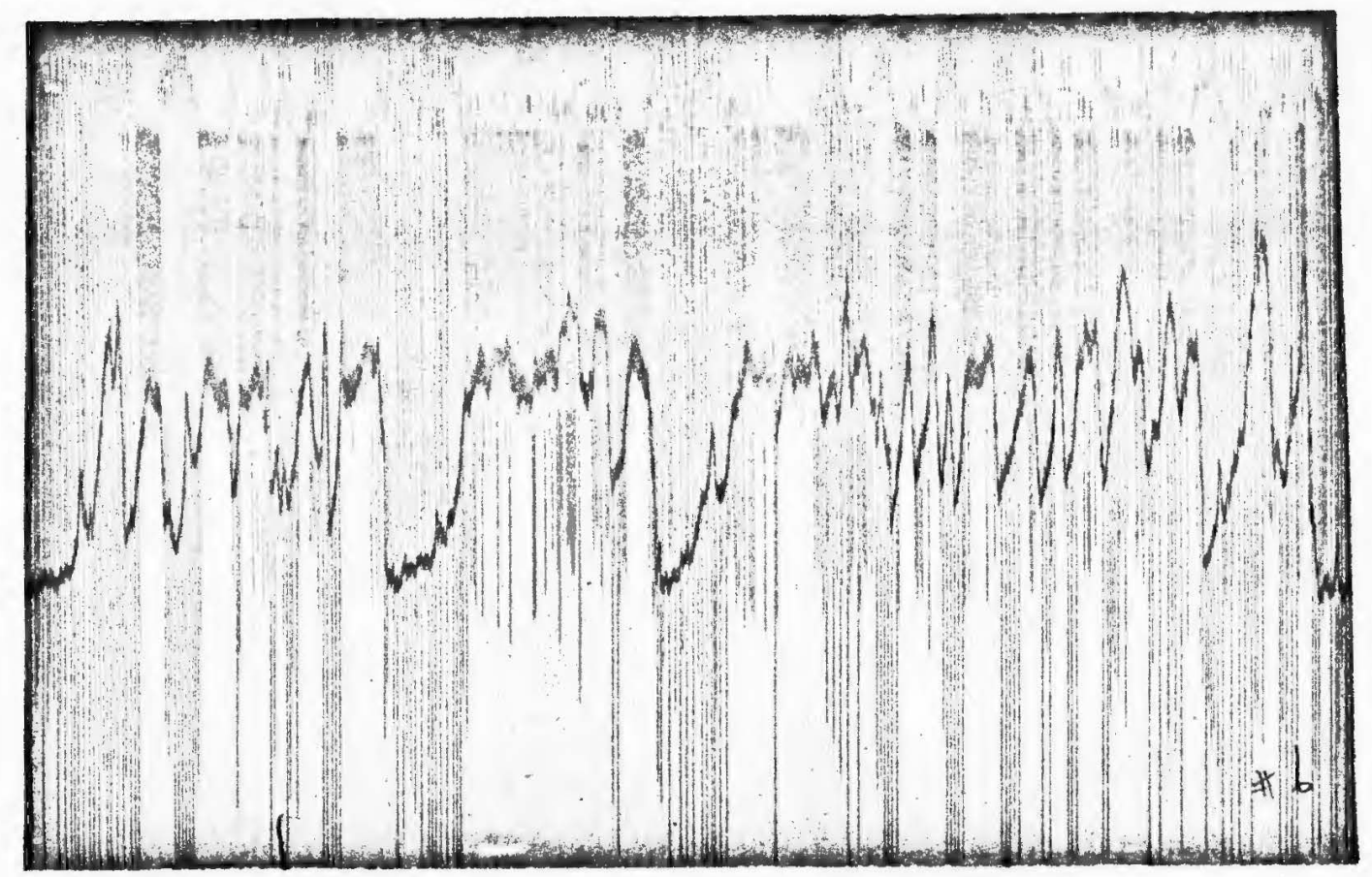

Figure 5 . The flattening of stress--equal stress upon almost all words--can be clearly seen in sentence \#6 of the highest rated student on the foreign accent rating.

Difficulty was also experienced by some speakers, whether poor or above average, with stressing on adjectives and nouns (16 percent) and pronouns (28 percent) and proper pitch on questions (8 percent).

The causes for these problems and the degree of significance to be given to them in teaching the Japanese learner will be described in the following chapter. 


\section{CHAPTER VII}

\section{SOURCES OF LEARNER ERRORS}

Some of the problems described in Chapter VI are faced not only by the Japanese speaker but by al1 language learners. However, most of these problems have been intensified by factors in the subjects' mother tongue.

Except for sentence $\# 2$, all of the errors found in the remaining ten sentences of the accent inventory could be traced back to the mother tongue. Strategies of second language learning and communication may have been involved but were not measurable. It is believed that the cause of learner difference in stressing in sentence \#2 was a transfer of training and overgeneralization of that particular stressing pattern.

\section{STRONG-WEAK STRESS PATTERN}

The fact that a common pattern of strong to weak stress was evident in the speech of all the subjects may be attributed to two characteristics of the subjects' mother tongue. Japanese possesses a large number of what may be called "enclitic elements" (particles being the most common); some of these make intelligible the grammatical construction of an utterance (Abe, 1955; Bloch, 1946; Kuno, 1973; and Niwa, 1966), while others impart an emotional coloring to an expression. In the mind of the average person, according to Abe, these elements are a 
kind of invisible intonation. It may therefore be argued that, in some instances, intonation is secondary and the lack of it does not do much damage to meaning as long as an adequate selection of words is made. This is true in the case of Japanese questions and is thus related to the lack of change in stressing by the Japanese learner in English questions. Although women may drop the particle "ka" at the end of questions and rely simply upon rising pitch, it is generally this particle that identifies a question and is adequate enough for the Japanese hearer to realize a question has been asked. Thus, the vast field of "phonogramic" words in Japanese make it possible, if one so desires, to dispense with other devices of expression and yet meet one's communication needs. Abe (1955, p. 391) has quoted another Japanese linguist, Motoki Tokieda, as stating, "If we had not developed in this language various types of word forms to indicate sentence structures, we would have developed other means of doing so."

This problem and the more specific but less major problems of stress on adjective-noun combinations and pronouns are related to the type of stressing used in the two languages as well. Corder (1973) has pointed out that languages are divided into two groups in relation to sentence stress, those in which it is the regular occurrence of the lap syllable which determines rhythm irrespective of stress and those with rhythm in which stresses occur at regular intervals irrespective of the number of intervening unstressed syllables. Gapanese is of the former type and English of the latter. In addition, in Japanese equal stress is placed on all syllables and equal duration is given to each syllable no matter how fast it is spoken (Bloch, 1950, p. 202). The Japanese 
written language consists of Chinese characters and two phonetic systems, hiragana and katakana, used for Japanese and foreign words, respectively. All Japanese words use consonant-vowel combinations of equal length with the exception of a long "0" sound. This contributes to the stressing pattern and to the segmentation which exists in the English of the Japanese learner.

\section{SEGMENTATION}

Syllable-timing, the equal stress on each syllable, and the equal duration of all syllahles in Japanese also contributed significantly to the problems of segmentation found in the speech of the subjects of this study. Not only are the words in the Japanese language made up of syllables given equal duration and stress, but the Japanese also tend to read and think of each character separately in their language. This reading habit carried over into English leads to what Bedford (1974a, p. 35) has termed "typewriter English." It destroys the intonation contour and rhythm necessary for understanding English. English sentences are spoken with recurrent bursts of speed, with long or short pauses or with intonation breaks between. This has been described as the grouping or linking of words. The groups themselves have been referred to as rhythm units (Pike, 1945, p. 109) and may also be considered as thought groups.

This word-by-word speech also leads to unnatural pronunciation. Pike stated that no matter how much words may be practiced for their pronunciation, the speech of the student will not sound natural until the words are pronounced within the context of a sentence. His advice 
to Spanish learners, who also have a syllable-timed language, applies to the Japanese as well. Syllable-to-syllable or word-by-word speech must be abandoned and syllables and words must be jammed together or lengthened where necessary. The lengths of English syllables differ with each utterance and are not controlled only by the lexical phonetic characteristics of their sounds but also by the accident of the number of syllables in a particular rhythmic unit.

\section{EQUAL STRESSING}

Thus, for the below-average to average Japanese learner of English segmentation is a problem. For the above-average student, however, flattened or equal stress on most or all words is a problem. The slower speaker, while he does segment his sentences, does have the time to consider where he may place some stress. The faster speaker, on the other hand, has learned to group his words together and to minimize pausing but has, in concentrating on these points, fallen back on the equal stressing pattern of his mother tongue.

\section{TERMINAL VOWEL SOUNDS}

The appearance of vowels at the ends of words terminating in consonants in the English speech of Japanese learners is also probably caused by language transfer. The Japanese have been borrowing foreign words for centuries (Gibney, 1975, pp. 146-7; Nagasawa, 1958, p. 83; Pierce, 1971, p. 45; Reischauer, 1977, p.397; and Vos, 1963). In recent years, these borrowings have tended to be more and more from American English. The borrowings have proved to be a handicap, especially in 
relation to articulation, enunciation, and clarity in the rhythm of the English speech of Japanese. The majority of Japanese words end in vowel sounds because of the consonant-vowel combination of which the Japanese language is made. This is carried over into the articulation of English words adopted into Japanese and when new English words are learned in the study of English these patterns are carried over into English speech.

Ohso (1973, p. 100) has stressed the fact that after palatalized or palatal consonants $|\mathbf{i}|$ or $|u|$ may be used with Japanese words and with loan words adopted into Japanese. The former is inserted in the case of palatalized velars and palatal affricates whereas $|u|$ is inserted with palatal spirants. She has also indicated that $10 \mid$ would follow the consonants $|t|$ and $|d|$.

\begin{tabular}{ll} 
English & Japanese \\
\hline match & macchi \\
page & peeji \\
fresh & fureshu \\
big league & biggu riigu \\
bag & baggu \\
hit & hitto \\
bed & beddo
\end{tabular}

According to Ohso, these vowels may be devoiced in fast speech. The number and variety of speakers who had problems with the terminal vowel in their English would indicate this not to be clearly the case when Japanese speak English.

While considering the mother tongue to be the source of the terminal vowels added to loan words, Ohso has also indicated that there may be a universal preference for the open syllable. This universal preference may combine with other processes, such as language transfer, to 
produce an even stronger preference for the open syllable in the interlanguage of some learners.

\section{EXCESSIVE PAUSING}

However, excessive pausing contributed more significantly to the ratings received by the subjects of this study. But it cannot be considered to originate from the mother tongue. Black et al. (1966, p. 238) found in a study of seventy-two foreign students that the average student's pausing pattern does not differ from that of his mother tongue. Crystal (1969), Black et al. (p. 238) and Goldman-Eisler (1961) have also emphasized that pausing is highly idiosyncratic. The best explanation, therefore, for the excessive pausing in the speech of 52 percent of the students in the study is a lack of proficiency in the language.

\section{INTRALINGUAL INTERFERENCE}

Neither language transfer nor a lack of proficiency is believed to be the source of the stressing pattern in sentence \#2. The stress placed on the question word in this sentence may have been caused by a transfer of training and an overgeneralization of the particular stress rule. It is surmised that this was the pattern employed by Japanese English teachers when teaching these types of questions to junior and senior high school students. The teacher may have been attempting to elicit a particular type of answer and therefore placed extra stress on the question word to make this clear to his students. He, unfortunately, did not indicate whether this was the most common pattern used. This is 
understandable since emphasis in the Japanese English classroom is more often on grammar and translation than on the spoken language. When the subjects included in this study entered college and began to study spoken English they overgeneralized what they had learned in junior and senior high school and applied it to all question-word questions. Those students whose stress patterns were closer to those of the native speakers had obviously employed strategies of second language learning in realizing the difference and overcoming it. These same strategies were successfully employed by the better speakers in becoming aware of and learning proper stress and rhythm patterns. However, at the present time it is not possible to measure to what extent these strategies influence the learning of English rhythm patterns.

\section{GRAMMAR-TRANSLATION STUDY AND FOREIGN ACCENT}

In conjunction with the analys is of errors described a secondary study was carried out. In order to discover whether seven years of English oriented toward grammar and translation with a minimal amount of speaking practice had any influence on abilities in speaking English, a secondary study was done in which the academic records of the subjects' first year translation course in college were compared with the ratings on foreign accent. The results were not conclusive as can be seen in Figure 6 . While high academic records in translation did not correlate with a high rating score on the foreign accent rating neither was there conclusive evidence that there was no relationship. The majority of the subjects had academic grades in the 80 s while the foreign accent ratings ranged from poor to excellent. Four students whose 
records academically in translation were not good also had poor accent ratings. Two students with poor academic scores had rather high ratings on accent.

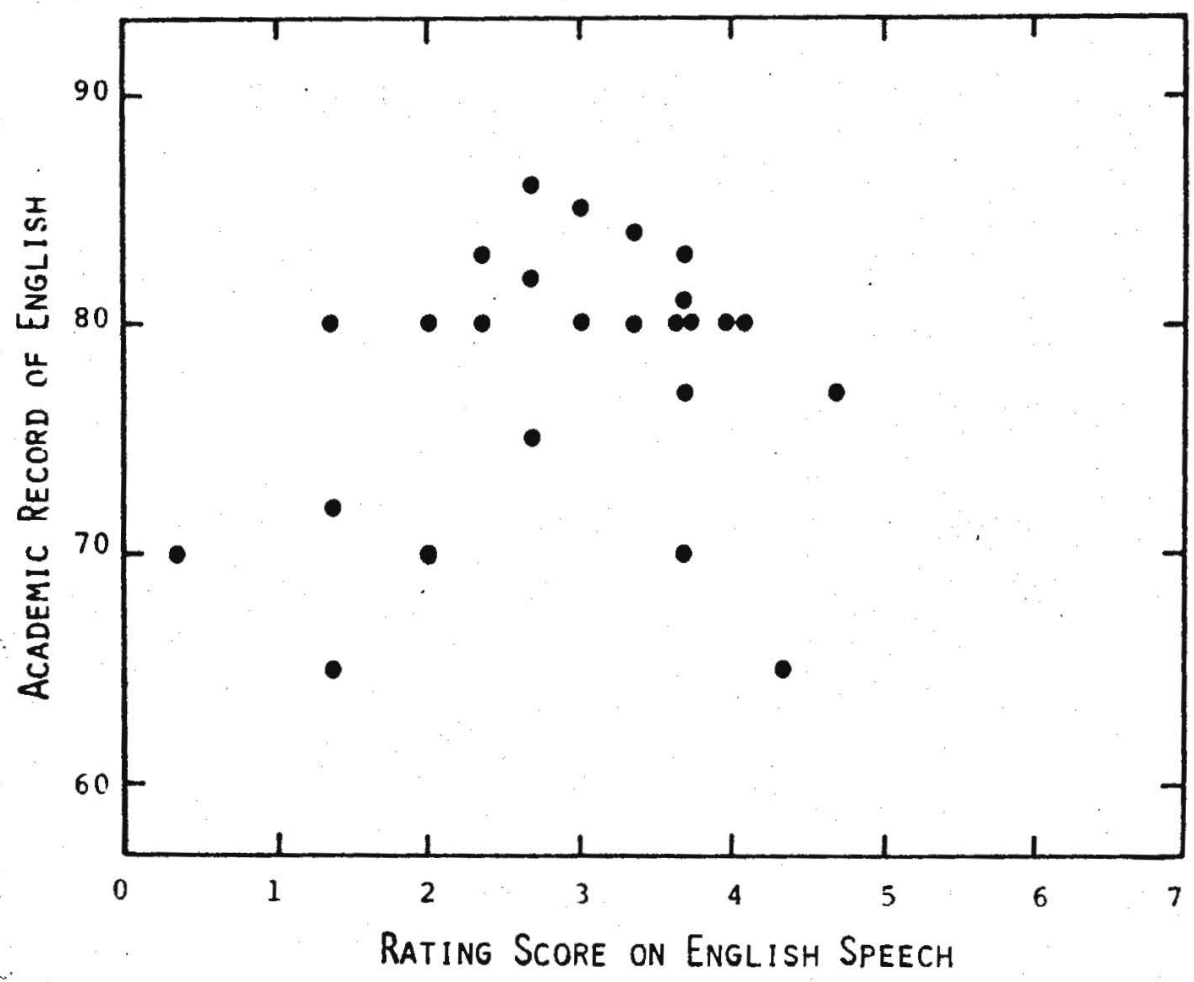

Figure 6. A reverse-u correlation exists between academic records on translation and the subjects' foreign accent ratings. 


\section{CHAPTER VIII \\ CONCLUSIONS AND RECOMMENDATIONS}

\section{SUMMARY}

The Japanese have every need and incentive to study a foreign language. To an outsider visiting Japan it may seem that they have every opportunity to do so. English is taught for six years in junior and senior high school. It is taught for at least one more year in college. Private English schools, institutes, courses on tape, and tutoring services can be numbered in the thousands. However, the results have not been impressive. Reading and writing ability are poor and speaking ability is poorer. A combination of obstacles--educational, sociocultural, and linguistic--contribute to the poor results achieved in Japan.

\section{CONCLUSIONS}

The education of young people in Japan is oriented toward the passing of university entrance examinations. Since it is not feasible at present to test speaking or hearing ability on the large scale required for these examinations, emphasis is placed on grammar, transiation, and reading in that order of importance. This leads to a distortion of junior and senior high school curriculums. A lack of proficiency in speaking English on the part of Japanese English teachers is another educational obstacle. It has been suggested that part of the 
cause for this is involved with the present requirements for an English teaching license. There may be over five hundred English conversation schools in Japan, but the quality of teaching staff and materials is not well controlled.

There are sociocultural influences which also make it difficult for the Japanese to learn English. Bedford (1974a) has called these cultural constraints. A11 aspects of life are carried on by tightly organized groups which exert powerful psychological influence to bind their members. Concern with relative status and group identification tends to make most Japanese uneasy when meeting someone they do not know and whose ideas or behavior may, therefore, be unpredictably individualistic or at least not classifiable. The need to conform leads to greater concern with loss of face. Ridicule is employed by teachers from the earliest years of school. This leads to a situation in which the English learner uses only those sentences he is certain are correct. These characteristics of Japanese culture deprive the learner of opportunities to practice and acquire English. There is also a question of motivation. Are junior and senior high school students motivated by anything more than entrance examinations in their study of English? Are many adults who do not need the language for business simply studying for recreation?. These questions could not be answered in this thesis.

Numerous linguistic differences act as obstacles to learning English also. Some of the problems faced by the Japanese language learner were considered through an error analys is of rhythm. Three possible sources for errors were considered: language transfer, intralingual interference, and the universal hierarchy of difficulty (which 
encompassed strategies of second language learning and communication). It is believed that language transfer is the major, but not the only, cause of language errors. The findings of this study supported this. A strong-weak stress pattern, segmentation on the part of belowaverage students, flattened stress on the part of better students, and terminal vowel sounds at the end of words ending in consonants could al1 be traced to characteristics of the Japanese pronunciation and intonation systems. But there was also the possibility that students had learned certain incorrect patterns from their teachers. This appeared in the question-word question that was part of the accent inventory used in the study. It was also obvious that better speakers had used strategies of second language learning and communication in identifying factors of the target language which needed to be learned and in learning how to acquire them. A foreign accent rating used in the study showed correlation between the number of types of errors, total phonation and pause time, and the amount of foreign accent.

\section{RECOMMENDATIONS}

The first step to any improvement in the teaching of English is a change in its relationship to the entrance examinations. Reischauer's (1977, p. 399) suggestion that English be divorced from the entrance examinations is probably the best suggestion. This is certainly more acceptable than adopting a dialect called Englic (combining Japanese and English) or teaching the history of languages but not the languages themselves (Kunihiro, 1977, p. 25; Nakao, 1975, p. 11). However, if English is divorced from the entrance examinations it must still remain 
computsory in junior and senior high school. However, if the examinations can be made comprehensive a well-balanced program may be developed. Most important of all, now and after changes in the university entrance examinations and the curriculum, is teacher reeducation. The feasibility of such programs including overseas study is rather doubtfut. However, programs such as that described by Fukuda (1975) and that of the Ministry of Education employing five native speakers could and should be expanded.

The suggestions made by Bedford (1974a, p. 40) for more stringent licensing requirements would also be helpful. If a well-balanced program existed in the public education system, the large majority of poor English conversation schools would close. Those that did remain open, however, would have to be required to follow more stringent regulations for teacher recruitment and the quality of teaching materials.

English speakers teaching in Japan in particular should be aware of the sociocultural factors which make the learning of a foreign language more difficult for the Japanese. It may enable them to construct teaching programs that will be more effective.

The present study has made it clear that the Japanese have problems with stressing and segmentation in their speech. These problems exist to some extent for all language learners, but the particular characteristics of the Japanese language make it more of a problem for the Japanese. Future textbooks should deal with these problems as well as with the well-known problems Japanese have with pronunciation. Such material could include the all-out use of contractions with be, have, and the auxiliaries when used with pronoun subjects, the reduction of 
unstressed voweis, the avoidance of pausing, and a greater amount of practice in using stress and intonation to carry meaning.

More specifically, in dealing with the teaching of intonation, the tapes used in the present thesis, along with magnetic tapes, could prove a useful tool. In 1964 Rose Marie Vardanian did an experiment in which she attempted to teach English intonation by making use of an oscillograph. The experimental group involved was given visual representations of the intonation contours of their utterances and those of native speakers along with a tape recording. Only ten persons were involved and the experiment lasted three weeks. These factors may have influenced the lack of any significant difference found between the experimental group and a control group not given visual recordings.

Leon and Martin (Lantoff, 1976, p. 273) developed a device at the University of Toronto which they called a visualizer. Their device is more accurate and pedagogically superior to the oscilloscope for providing the student with intonation contours. The machine, which is linked to a computer, judges the accuracy of the student's response and immediately displays the contour of his utterance so that he is able to visually discern his degree of variance from the model. This machine seems particularly excellent; however, neither machine is intended for large classes. In Japan, classes usually would not be small enough to be able to use these systems. There would also be a substantial expense involved in installing and using them. The use of tapes such as those used in this thesis would not have these drawbacks. The one drawback would be a lack of instant feedback. Tape recordings could be made of the students' voices and they could be given visual copies of 
their intonation and that of a native speaker for comparison. A trained teacher could then explain the differences to the students and drill them on their weaknesses. New tapes could then be recorded to discover if any changes had been made.

A number of roads for further research on the subject of error analysis and intonation could be opened up based upon the present research. No comparison was made on tape or visually of rhythm or intonation patterns between Japanese and English. The effectiveness of the two methods of teaching intonation visually as well as aurally and that suggested in this thesis could also form three individual projects. A more detailed error analysis of the Japanese learner's English of intonation including pitch is also advisable. It would also be of value to consider in more detail the effectiveness of teacher education and of the English programs in Japanese junior and senior high schools and universities. The Japanese learner of English is still a somewhat untouched field of study. 


\section{A SELECTED BIBLIOGRAPHY}




\section{A SELECTED BIBLIOGRAPHY}

Abe, Isamu. "Intonational Patterns of English and Japanese." Word XI (December 1955):386-98.

"General Characteristics of Japanese Terminal Intonation with a Presentation of Its Notational System." Lingua XVI (1966): 255-62.

Akiyama, Takeshoro. "Teaching English on Radio and Television." ELEC Bulletin 55-56 (Autumn 1976):79-86.

Banathy, Bela H., and Madarasz, Paul H. "Contrastive Analysis and Error Analysis." Journal of English as a Second Language IV (Fal1 1969): 77-92.

Bedford, R. C. "Cultural Constraints on Communication." ELEC BuTletin 44 (Winter 1974):34-42.

- "Instruction for Direction or Direction for Instruction." ELEC Bulletin 48 (Winter 1975):20-5.

Black, J. W. et al. "A Study of Pauses in Oral Reading of One's Native Language and English." Language and Speech IX (1966):237-41.

Bloch, Bernard. "Studies in Colloquial Japanese II: Syntax." Language XXI I (1946):200-48.

"Studies in Colloquial Japanese IV: Phonemics." Language XXVI (1950): 86-125.

Bolinger, Dwight. "Around the Edge of Language: Intonation." Harvard Educational Review XXXIV (Spring 1964):282-93.

Bronsteen, Arthur J. The Pronunciation of American English: An Introduction to Phonetics. New York: Appleton-Century-Croft, 1960.

Burt, Marina K. "Error Analys is in the Adult EFL Classroom." TESOL Quarterly IX (March 1975):53-63.

Carro11, John B. "Contrastive Linguistics and Interference Theory." In Report of the Nineteenth Roundtable Meeting on Linguistics and Language Studies, pp. 113-22. Edited by James E. Alatis. Washington, D.C.: Georgetown University Press, 1968. 
Chandron, Craig. "A Descriptive Model of Discourse in the Corrective Treatment of Learners' Errors." Language Learning XXVII (June 1977) :29-46.

Cohen, Andrew D. "Error Analys is and Error Correction with Respect to the Training of Language Teachers." Working Papers in Teaching English as a Second Language IX (January 1975):107-24. California University, Los Angeles, Department of English.

- "Error Correction and the Training of Language Teachers." Modern Language Journal LIX:414-22.

Corder, S. P. "The Significance of Learners' Errors." IRAL V (1967): $161-9$.

- Introductory Applied Linguistics. Baltimore, Md.: Penguin Education, 1973.

"Idiosyncratic Dialects and Error Analysis." In Error Analysis: Perspectives on Second Language Acquisition, pp. 158-71. Edited by Jack C. Richards. London: Longman, 1974.

Cowen, Susie. "English Proficiency and Bicultural Attitudes of Japanese Students." Eigo Kyoiku--The English Teachers' Magazine XVII (December 1968):38-44.

Crystal, David. Prosodic Systems and Intonation in English. Cambridge: Cambridge University Press, 1969.

Delattre, Pierre. "The Distinctive Function of Intonation." In Intonation, pp. 159-74. Edited by Dwight Bolinger. Harmondsworth, EngTand: Penguin Books Ltd., 1972.

Denes, P., and Williams, J. Milton. "Further Studies in Intonation." Language and Speech V (1962):1-14.

Doi, Kochi. "Eigo o hanasu hayasa (The Tempo of English Speech)." Eigo Seinen--The Rising Generation CVIII (1962):554-7.

Duskova, L. "On Sources of Errors in Foreign Language Learning." International Review of Applied Linguistics VII (1969):11-36.

Fairbanks, Grant, and Hoaglin, Lemar W. "An Experimental Study of the Durational Characteristics of the Voice During the Expression of Emotion." Speech Monographs VIII (1941):85-90.

Finochiaro, Mary. Teaching English as a Second Language. 2nd ed. New York: Harper and Row, 1969.

Fletcher, Harvey, Speech and Hearing in Communication. Princeton, N.J.: D. Van Nostrand Co., Inc., 1953. 
Fries, C. C. Teaching and Learning English as a Foreign Language. Ann Arbor: University of Michigan Press, 1945.

Fukuda, Shohachi. "The Four-Year Teacher Training Project: Its Operation and Achievements." TESOL Quarterly IX (March 1975):15-22.

George, H. V. "English for Asian Learners: Are We on the Right Road?" English Language Teaching XXV (1971):270-7.

- Common Errors in Language Learning: Insights from English. Rowley, Mass.: Newbury House Publishers, Inc.

Gibney, Frank. "A Matter of Language." In Japan: The Fragile Superpower, pp. 144-62. Tokyo: Charles E. Tuttle Co., 1975.

Gimson, A. C. An Introduction to the Pronunciation of English. 2nd ed. London: Edward Arnold, 1972.

Goldman-Eisler, Frieda. "The Distribution of Pause Durations in Speech." Language and Speech IV (1961):232-7.

Goldstein, Bernice Z., and Tamura, Kyoko. Japan and America: A Comparative Study in Language and Culture. Rutland, Vt. and Tokyo: Charles E. Tuttle Co., 1975.

Gomes de Matos, F., and Short, A. Green. "Improving Your American English Pronunciation: Intonation." Creativity: New Ideas in Language Teaching, No. 20 (September 1976). Instituto de Ichemas Yazigi, Sao Paulo.

Gordon, Morton J. Speech Improvement: A Practical Guide for Native and Non-Native Speakers of English. Englewood Cliffs, N.J.: PrenticeHall, 1974.

Grate, Harriette Gordon. English Pronunciation Exercises for Japanese Students. New York: Regents Publishing Co., Inc., 1974.

Gunter, Richard. "Intonation and Relevance." In Intonation, pp. 194215. Edited by Dwight Bolinger. Harmondsworth, England: Penguin Books Ltd., 1972.

Harasawa, Masayoshi. "Linguistic Inefficiency--An Inquiry into Its Causes--The Root of All Evil." Eigo Kyoiku--The English Teachers' Magazine XXIII (June 1974):32-3.

- "Linguistic Inefficiency--An Inquiry into Its Causes--The Theory of Vicarious Study." Eigo Kyoiku--The English Teachers' Magazine XXIII (August 1974): $: \frac{62-3 .}{}$ 
Hashimoto, Sadao, and Lau, Larry. "A Survey of In-Company English Teaching Programs." ELEC Bul letin 55-56 (Autumn 1976):75-8.

Hok, Ruth. "Contrast: An Effective Teaching Device." English Language Teaching XVII (1964):117-22.

Ito, Kenzo. "English Education in Japan: Teaching Materials." ELEC Bulletin 55-56 (Autumn 1976):59-65.

Jain, M. P. "Error Analysis: Source, Cause and Significance." In Error Analysis: Perspectives on Second Language Acquisition, pp. 189-215. Edited by Jack C. Richards. London: Longman, 1974.

James, Max H. "A Tentative Study of the Intonation of Japanese." Language Learning VII (1957):35-49.

Japan Ministry of Education. Educational Standards in Japan: The 1970 "White Paper" on Education. March 1971. - Mombusho: English Fellows Program. 1977-78 Announcement.

Jones, Daniel. The Pronunciation of English. Cambridge: The University Printing House, 1973.

Kess, Joseph F. "English Influences in the Phonology of Japanese Spoken in Hawaii." Proceedings of the Linguistic Society of New Zealand X-XI $(1967-1968): 27-39$.

Kingdon, Roger. The Groundwork of English Intonation. London: Longman, 1958.

Knowles, G. "The Rhythm of English Syllables." Lingua XXXIV (SeptemberOctober 1974):115-47.

Kunihiro, Masao. "Panel Discussion: Which Should We Aim at, Accuracy or Expressiveness?" ELEC Bulletin 57 (Spring 1977):6-28.

Kuno, Susumu. The Structure of the Japanese Language. Cambridge, Mass.: The MIT Press, 1973.

Lantoff, James P. "On Teaching Intonation." The Modern Language Journal LX (September-October 1976):267-74.

Lehiste, Ilse, and Peterson, Gordon E. "Some Basic Considerations in the Analysis of Intonation." Journal of the Acoustical Society of America XXXIII (Apri1 1961) :419-25.

Leon, Pierre R., and Martin, Philippe. "Machines and Measurements." In Intonation, pp. 30-47. Edited by Dwight Bolinger. Harmondsworth, England: Penguin Books Ltd., 1972. 
Lewis, J. Windsor. A Concise Pronouncing Dictionary of British and American English. London: Oxford University Press, 1972.

Lieberman, Philip. Intonation, Perception, and Language. Research Monograph No. 38. Cambridge, Mass.: The MIT Press, 1967.

Magdics, K. "Research on Intonation during the Past Ten Years." Acta Linguistica XIII (1963):133-65.

Malmberg, Bertil. Phonetics. New York: Dover Publications, Inc., 1963.

Martin, Samue1 E. "On the Accent of Japanese Adjectives." Language XLIII (March 1967):246-77.

Miller, Roy Andrew. The Japanese Language. Chicago: University of Chicago Press, 1967.

Nagasawa, Jiro. "A Study of English-Japanese Cognates." Language Learning VIII (1958):53-93.

Nakao, Kiyoaki. "Confusion in Japan's English Teaching Circles." Gendaieigo Kyoiku--Modern English Teaching 7 (July 1975):10-11.

Nemser, William. "Approximative Systems of Foreign Language Learners." In Error Analysis: Perspectives on Second Language Acquisition, pp. 55-63. Edited by Jack C. Richards. London: Longman, 1974.

Niwa, Tamako, and Matsuda, Mayako. Basic Japanese for College Students. Seattle: University of Washington Press, 1966.

Niyekawa, Agnes. A Study of Second Language Learning: The Influence of First Language on Perception, Cognition and Second Language Learning--A Test of the Whorfian Hypothesis--Final Report. University of Hawaii Educational Research and Development Center, 1968.

Ogasawara, Linju. "The Educational System and English in Japan." ELEC Bulletin 55-56 (Autumn 1976):87-94.

Ohso, Mieko. "A Phonological Study of Some English Loan Words in Japanese." Working Papers in Linguistics, No. 14, Apri1 1973. Ohio State University, Department of Linguistics, pp. 1-37.

Ota, Akira. "The Study of English in Japan." In Current Trends in Linguistics: Vol. II, Linguistics in Asia and South East Asia, pp. 645-81. Edited by Thomas A. Sebeok. The Hague: MouTton, 1967.

- "Language Problems in Science and Technology Education in Japan." Eigo Kyoiku--The English Teachers' Magazine XXIV (June 1975):56-63. 
"English Education in Japan: Methods." ELEC Bulletin 55-56 (Autumn 1976): 48-58.

Pierce, Joe E. "Culture, Diffusion and Japlish." Linguistics 76 (December 1971):45-58.

Pike, Kenneth L. The Intonation of American English. Ann Arbor: University of Michigan Press, 1945.

Powel1, Christopher. "English Study--Facts and Fallacies." Gendaieigo Kyoiku--Modern English Teaching 7 (July 1975):26-8.

. "English Study--Facts and Fallacies." Gendaiego Kyoiku-Modern English Teaching 11 (November 1975):40-2.

Prator, Clifford R., Jr., and Robinett, Betty Wallace. Manual of American English Pronunciation. 3rd ed. New York: Holt, Rinehart and Winston, Inc., 1972.

Reischauer, Edwin 0. The Japanese. Cambridge, MA.: The Belknap Press of Harvard University Press, 1977.

Reid, Thomas. "English Teaching in the Public Schools." Eigo Kyoiku-The English Teachers' Magazine XXIII (August 1974):43-5.

Richards, Jack C., and Sampson, Gloria. "The Study of Learner English." In Error Analysis: Perspectives on Second Language Acquisition, pp. 3-18. Edited by Jack C. Richards. London: Longman, 1974.

Richards, Jack C. "Social Factors, Interlanguage, and Language Learning." In Error Analysis: Perspectives on Second Language Acquisition, pp. 64-97. Edited by Jack C. Richards. London: Longman, 1974.

Schachter, J. "An Error in Error Analysis." Language Learning XXIV (1974):205-11.

Schmerling, Susan F. "A Re-examination of 'Normal Stress.'" Language L (March 1974):66-73.

Selinker, Larry. "Interlanguage." In Error Analysis: Perspectives on Second Language Acquisition, pp. 31-54. Edited by Jack C. Richards. London: Longman, 1974.

Shapiro, Michael. "Tenues and Mediae in Japanese: A Reinterpretation." Lingua XXIII (1974):101-14.

Sharp, A. "Falling-Rising Intonation Patterns in English." Phonetics II $(1958): 127-52$. 
Sridhar, S. N. "Contrastive Analysis, Error Analysis and Interlanguage: Three Phases of One Goal?" Studies in Language Learning I (Fal1 1975): $93-128$.

Takefuta, Yukio, and Black, John W. "A Study of Foreign Accent in Japanese English." Speech Monographs XXXIV (1967):167-70.

Tarone, Elaine. "Some Influences on Interlanguage Phonology." Working Papers on Bilingualism 8 (1972):87-111. Ontario Institute for Studies in Education, Toronto. Bilingual Education Program.

Taylor, Barry P. "The Use of Overgeneralization and Transfer Learning Strategies by Elementary and Intermediate Students of ESL." Language Learning XXV (June 1975):73-107.

Taylor, Linda L. et al. Psychological Variables and Ability to Pronounce a Second Language. Ann Arbor: University of Michigan Center for Research on Language and Language Behavior, 1969.

Torii, Tsugiyoshi. "The Training of English Teachers in Post-war Japan." ELEC Bulletin 55-56 (Autumn 1976):66-74.

Umegaki, Minoru. Nichei Hikaku Hyogen Ron (Comparison of Japanese and English Expressions). Tokyo: Taishukan, 1975.

Vardanian, R. M. "Teaching English Intonation through Oscilloscope Displays." Language Learning XIV (1964):109-17.

Vos, F. "Dutch Influences on the Japanese Language." Lingua XII (1963):341-56.

Wardhaugh, Ronald. "An Evaluative Comparison of Present Methods for Teaching English Phonology." TESOL Quarterly IV (March 1970): 63-72.

Whitman, R. L., and Jackson, K. L. "The Unpredictability of Contrastive Analysis." Language Learning XXII (1972):29-41. 


\section{APPENDIX}




\section{APPENDIX}

Three native listeners were asked to listen to the tapes of twenty-five Japanese English speakers and rate the amount of foreign accent they perceived in relation to the rhythm of speech. Subjects were rated from one to seven, with seven being the equivalent of a native speaker. A copy of the rating sheet appears on the next page. 
FOREIGN ACCENT RATING SHEET

1. Watanabe

2. Ide

3. Kawana

4. Ishiyama

5. Motoe

6. Kon

7. T. Miura

8. Abe

9. Fujibayashi

10. Kodama

11. T. Kimura

12. J. Miura

13. Fukuoka

14. Hosoya

15. N. Kimura

16. Ito

17. Niida

18. Ikeda

19. Numazaki

20. Okubo

21. Shirase

22. Kobayashi

23. Honma

24. Morita

25. Miyamoto
2

2

2

2

2

2

2

2

2

2

2

2

2

2

2

2

2

2

2

2

2

2

2

2

2

\begin{abstract}
3
\end{abstract}
3

3

3

3

3

3

3

3

3

3

3

3

3

3

3

3

3

3

3

3

3

3

3

3
4.

4

4

$4 \quad 5$

4

4

4

4

4.5

$4 \quad 5$

$4 \quad 5$

4.

4

4

4

4

4

4

$4 \quad 5$

$4 \quad 5$

4

4

4

4

4 